San Jose State University

SJSU ScholarWorks

Master's Theses

Master's Theses and Graduate Research

1993

\title{
Onshore and offshore effects of the 1989 Loma Prieta Earthquake in the Moss Landing, California area
}

Robert Francis Barminski

San Jose State University

Follow this and additional works at: https://scholarworks.sjsu.edu/etd_theses

\section{Recommended Citation}

Barminski, Robert Francis, "Onshore and offshore effects of the 1989 Loma Prieta Earthquake in the Moss Landing, California area" (1993). Master's Theses. 670.

DOI: https://doi.org/10.31979/etd.nzyh-t8e3

https://scholarworks.sjsu.edu/etd_theses/670

This Thesis is brought to you for free and open access by the Master's Theses and Graduate Research at SJSU ScholarWorks. It has been accepted for inclusion in Master's Theses by an authorized administrator of SJSU ScholarWorks. For more information, please contact scholarworks@sjsu.edu. 


\section{INFORMATION TO USERS}

This manuscript has been reproduced from the microfilm master. UMI films the text directly from the original or copy submitted. Thus, some thesis and dissertation copies are in typewriter face, while others may be from any type of computer printer.

The quality of this reproduction is dependent upon the quality of the copy submitted. Broken or indistinct print, colored or poor quality illustrations and photographs, print bleedthrough, substandard margins, and improper alignment can adversely affect reproduction.

In the unlikely event that the author did not send UMI a complete manuscript and there are missing pages, these will be noted. Also, if unauthorized copyright material had to be removed, a note will indicate the deletion.

Oversize materials (e.g., maps, drawings, charts) are reproduced by sectioning the original, beginning at the upper left-hand corner and continuing from left to right in equal sections with small overlaps. Each original is also photographed in one exposure and is included in reduced form at the back of the book.

Photographs included in the original manuscript have been reproduced xerographically in this copy. Higher quality $6^{\prime \prime} \times 9^{\prime \prime}$ black and white photographic prints are available for any photographs or illustrations appearing in this copy for an additional charge. Contact UMI directly to order.

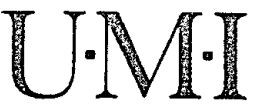



Order Number 1356453

Onshore and offshore effects of the 1989 Loma Prieta earthquake in the Moss Landing, California area

Barminski, Robert Francis, Jr., M.S.

San Jose State University, 1993

Copyright (C)1993 by Barminski, Robert Francis, Jr. All rights reserved.

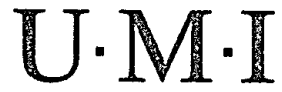

300 N. Zeeb Rd.

Ann Arbor, MI 48106 



\title{
ONSHORE AND OFFSHORE EFFECTS \\ OF THE 1989 LOMA PRIETA EARTHQUAKE \\ IN THE MOSS LANDING, CALIFORNIA AREA
}

\author{
A Thesis \\ Presented to \\ The Faculty of Moss Landing Marine Laboratories \\ San Jose State University
}

\author{
In Partial Fulfillment \\ of the Requirements for the Degree \\ Master of Science
}

by

Robert Francis Barminski Jr.

December, 1993 
( 1993

Robert F. Barminski Jr.

ALL RIGHTS RESERVED 
APPROVED FOR MOSS LANDING MARINE LABORATORIES

Willow Brent

Dr. William W. Broenkow
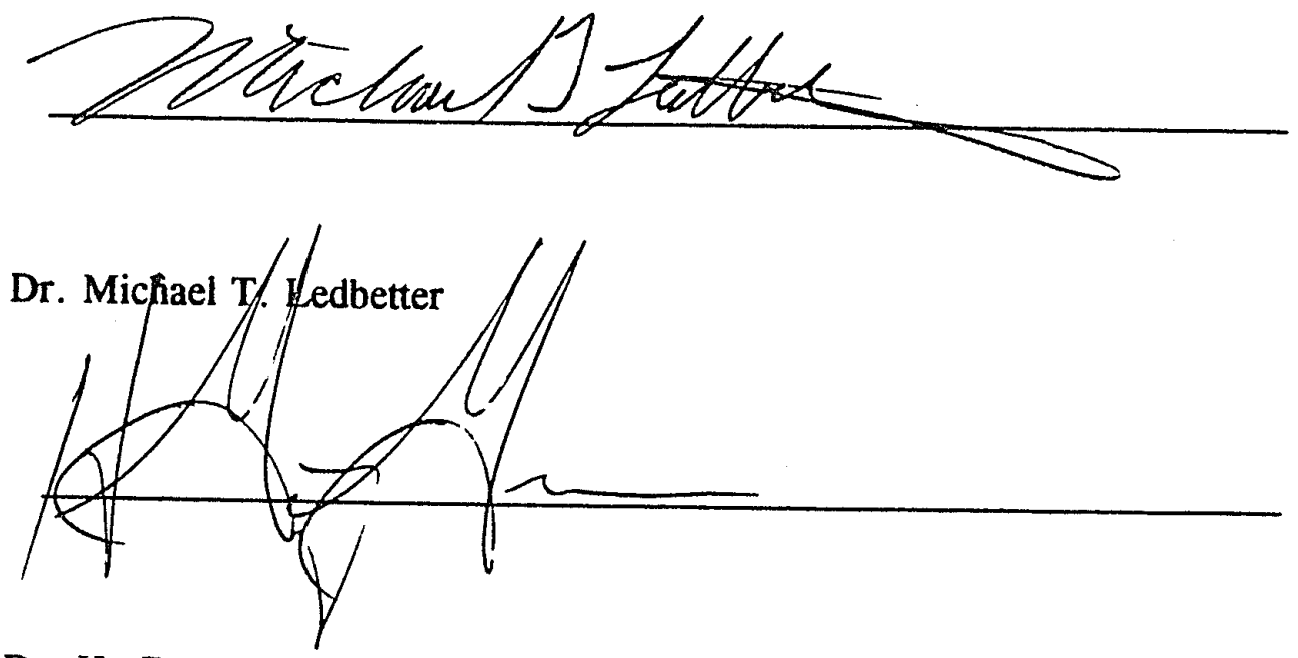

Dr. H. Gary Greene

APPROVED FOR THE UNIVERSITY

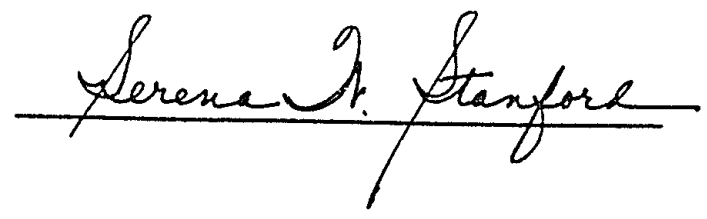




\section{ABSTRACT \\ ONSHORE AND OFFSHORE EFFECTS \\ OF THE 1989 LOMA PRIETA EARTHQUAKE \\ IN THE MOSS LANDING, CALIFORNIA AREA}

by Robert F. Barminski Jr.

Ground failure and shaking during the October 17, 1989 Loma Prieta earthquake damaged numerous buildings in Moss Landing, California. Areas of greatest ground movement from the 1906 and 1989 Loma Prieta earthquake coincided. Areas of liquefaction correlated with historical shorelines, sewer line breaks, and age of sediments. Factors controlling the distribution and severity of damage are the geological properties of shallow soil horizons, duration of shaking, and proximity to the head of Monterey Canyon. The primary zone of liquefaction was the upper three to four meters of Holocene sand. Subsurface exploration defined the lateral continuity and vertical thickness of liquefiable horizons. Offshore investigations at the head of Monterey Canyon identified slope failures that correlate with onshore liquefaction horizons. The earthquake effects in the Moss Landing area may be typical for similar coastal areas adjacent to submarine canyons. 


\section{ACKNOWLEDGEMENTS}

I would like to acknowledge the help and support of many people without whom this thesis would not have been completed, especially the members of my committee, Mike Ledbetter and Gary Greene, for providing guidance and encouragement throughout this project. I thank the captains and crews of the R/V Point Sur and R/V Ed Ricketts. Unique photographic evidence was gathered by Tom Chase of the U.S. Geological Survey. John Rutherford shared information as did other consultants. Information was provided by the Moss Landing Harbor District and San Jose State University. Fellow Moss Landing students Joan Gardner-Taggart and Judy Mariant helped in the field as did Mike Barminski and Bill McGovern. My wife and children patiently forebore my frequent absences during work on this project. I would like to remember Dr. John Martin for financial help for seismic surveying. Research was also supported by NSF Grant OCE-05970.

Inspiration for this project has come from the faculty, staff, and students of Moss Landing Marine Laboratories. The greatest earthquake damage at Moss Landing was the destruction of the laboratory. Fortunately, no one was killed or seriously injured. Unfortunately, important research projects and academic careers were interrupted. It will take years of effort to rebuild the unique learning environment of Moss Landing Marine Laboratories. Fortunately, the people of the Laboratories have shown the resilience and fortitude needed to complete the renewal. 


\section{TABLE OF CONTENTS}

ACKNOWLEDGEMENTS $\ldots \ldots \ldots \ldots \ldots \ldots \ldots \ldots \ldots \ldots$ iv

LIST OF FIGURES AND TABLES $\ldots \ldots \ldots \ldots \ldots \ldots \ldots \ldots \ldots$ vii ABSTRACT $\ldots \ldots \ldots \ldots \ldots \ldots \ldots \ldots \ldots \ldots \ldots \ldots \ldots \ldots \ldots \ldots \ldots$ viii

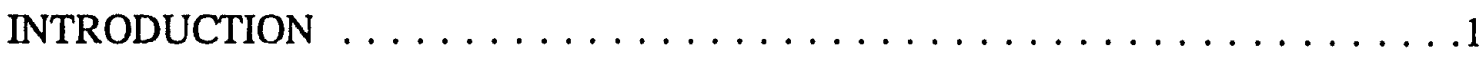

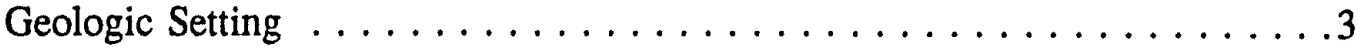

Loma Prieta Earthquake $\ldots \ldots \ldots \ldots \ldots \ldots \ldots \ldots \ldots \ldots$

Earthquake Effects at Moss Landing $\ldots \ldots \ldots \ldots \ldots \ldots \ldots$

Previous Earthquakes $\ldots \ldots \ldots \ldots \ldots \ldots \ldots \ldots \ldots \ldots \ldots \ldots$

Historical Shorelines $\ldots \ldots \ldots \ldots \ldots \ldots \ldots \ldots \ldots \ldots \ldots$

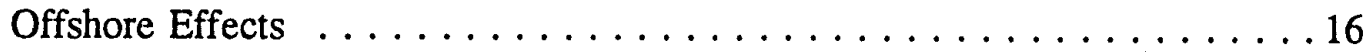

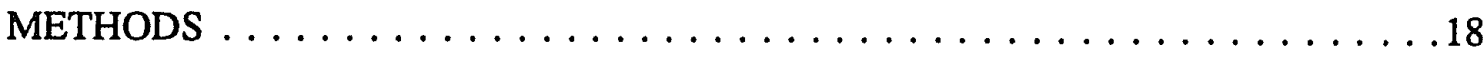

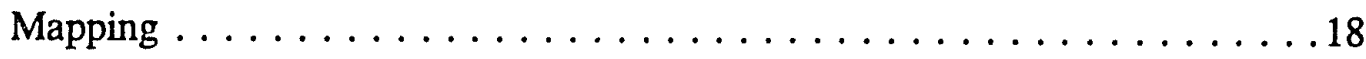

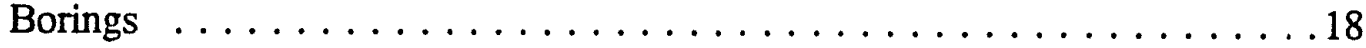

Geophysical Surveying $\ldots \ldots \ldots \ldots \ldots \ldots \ldots \ldots \ldots \ldots \ldots \ldots \ldots \ldots$

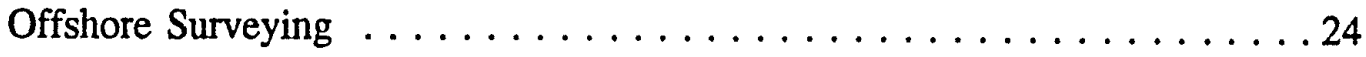

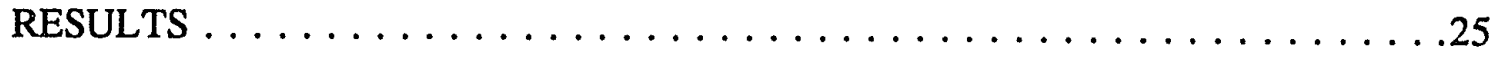

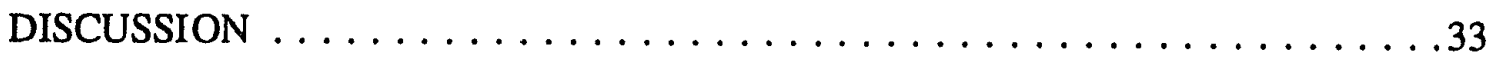

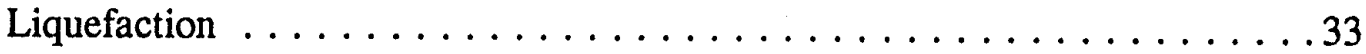

Ground Motion $\ldots \ldots \ldots \ldots \ldots \ldots \ldots \ldots \ldots \ldots \ldots \ldots \ldots \ldots \ldots \ldots \ldots \ldots$

Shear Wave Analyses . . . . . . . . . . . . . . . . 38 


\section{TABLE OF CONTENTS (continued)}

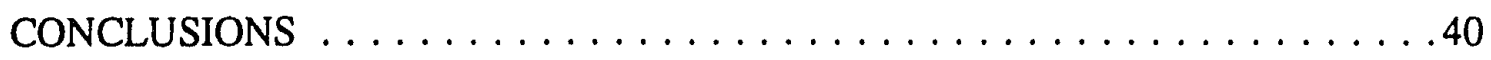

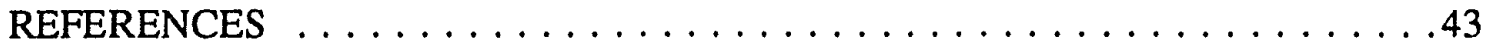




\section{LIST OF FIGURES AND TABLES}

Figures

Page

1. Bathymetric map of nearshore zone, Moss Landing California . . . . . . 2

2. Sketch map of Moss Landing, California spit and harbor $\ldots \ldots \ldots \ldots$

3. A, B, C, D: Liquefaction effects on Moss Landing spit $\ldots \ldots \ldots \ldots$

4. A, B, C, D, E, F: Comparison of 1906 and 1989 earthquake damage . . . . 13

5. A, B, C: Shoreline locations in 1849,1910 , and $1933 \ldots \ldots \ldots$

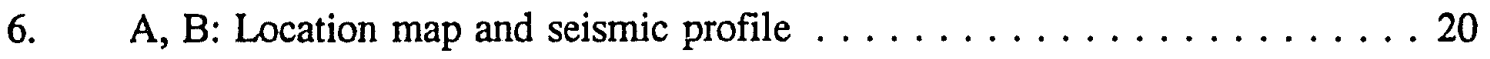

C, D: Geologic cross sections ....................... 21

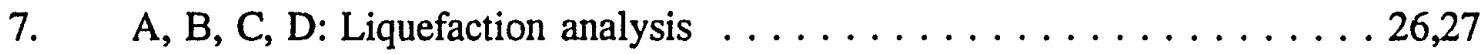

8. A, B: Ground deflection at General Fish and MBARI . . . . . . . 30

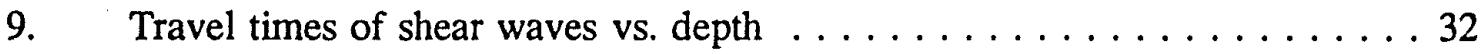

Tables

1. Summary of site conditions at Moss Landing $\ldots \ldots \ldots \ldots$ 


\begin{abstract}
Ground failure and shaking during the October 17, 1989 Loma Prieta earthquake resulted in structural damage to numerous buildings in Moss Landing, California. Areas of greatest ground movement and damage from the 1906 and 1989 Loma Prieta earthquake were coincident. Factors controlling the distribution and severity of damage include geological properties of shallow soil horizons, intensity and duration of shaking, type of construction, and proximity to the head of Monterey Canyon. Post earthquake field mapping of areas of liquefaction revealed a correlation with age of sediments and sewer line breaks. Lateral spreading was restricted to late Holocene beach deposits. Liquefaction analysis and inclinometer data indicate that the zone of liquefaction extends to a maximum depth of 8.5 meters. Fine-grained layers at depth inhibit the mobilization of deeper sand layers. Subsurface exploration utilizing hollow-stem auger and rotary wash methods as well as seismic profiling and shear wave velocity analysis define the lateral continuity of liquefible soil horizons and are used to relate the vertical thickness of these horizons to liquefaction severity. Offshore investigations at the head of Monterey Canyon utilizing side-scan sonar, seismic profiling, and SCUBA identified zones of slumping and mass wasting that relate to onshore liquefaction horizons. Liquefaction effects in the Moss Landing area may be typical for similar coastal areas adjacent to submarine canyons.
\end{abstract}




\section{INTRODUCTION}

The Ms 7.1 earthquake that occurred on October 17, 1989 in the Santa Cruz Mountains was the largest earthquake to strike the Monterey Bay area since the great San Francisco earthquake of 1906 . The 1989 earthquake ruptured an approximate 40 kilometer (km) segment of the San Andreas fault and Modified Mercalli Intensity was estimated to be as high as VII for the Moss Landing area (Fig. 1) (Plafker and Galloway, 1989). Several old canneries as well as the modern research facilities of the Moss Landing Marine Laboratories (MLML) and Monterey Bay Aquarium Research Institute (MBARI) occupied the spit prior to the earthquake, and approximately $75 \%$ of these buildings, including the MLML facility, were damaged or destroyed. The strong shaking lasted just fifteen seconds but caused over $\$ 12,000,000$ damage on the Moss Landing spit (Messick, 1989). Much of this damage was caused by liquefaction-induced ground deformation. The diverse sedimentary depositional history of Moss Landing and proximity to Monterey Canyon made this earthquake an extraordinary opportunity to study the effects of earthquake induced liquefaction on marine and non-marine environments. 


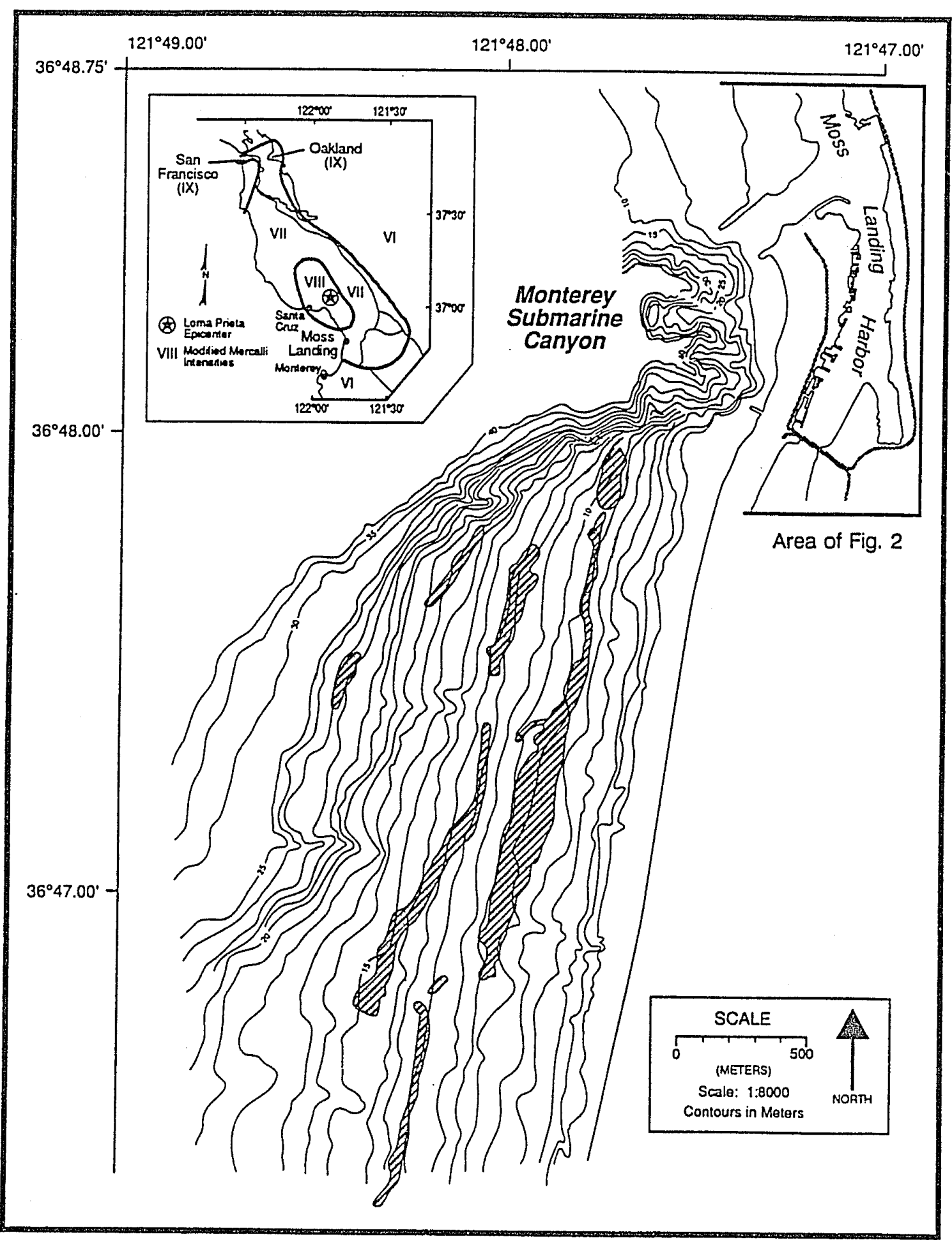

Figure 1: Bathymetric map of nearshore zone, Moss Landing, California. Shaded areas are offshore liquefaction zones interpreted from side-scan sonographs. Inset: Northern California coast showing location of epicenter of Loma Prieta earthquake and Modified Mercalli Intensity zones; modified after Plafker and Gallnway (1989). From Greene et al., 1991. 


\section{Geologic Setting}

The Monterey Bay region is located within the allocthonous structural-basement terrane known as the Salinian block (Page, 1989). The Salinian block is an elongated northwest-trending segment of the Coast Ranges, bounded on the northeast by the San Andreas fault and on the southwest onshore by the Sur-Nacimiento fault zone and offshore by the Palo Colorado-San Gregorio fault zone (Greene, 1977). In the Moss Landing area the Salinian block is composed of Cretaceous quartz-diorite overlain by the Tertiary Purisima Formation of marine sandstones, the Monterey Formation of siltstone and mudstone, Pleistocene Aromas sands and fluvial deposits, and Holocene marine, fluvial, and estuarine materials (Greene, 1977).

Moss Landing is a small estuary and fishing harbor located at the midpoint of the coastal arc inscribed by Monterey Bay (Fig. 1). Inland of the harbor is Elkhorn Slough, a tidal wetland that may represent a Pleistocene river channel (Dupré, 1975). Moss Landing spit is a low-laying peninsula that is 80 to 250 meters (m) wide in an east-west direction and the developed portion of the spit is about $615 \mathrm{~m}$ long in a north-south direction. Presently the Salinas River debouches south of Moss Landing, but before 1910 the Salinas River flowed into Monterey Bay north of the present harbor entrance (Gordon, 1987). During Pleistocene sea-level lowstands, the Salinas River meandered across the coastal plain incising eolian deposits and depositing fluvial sediment in its flood plain. During the latest rise in sea level, coastal dunes formed and the present-day Moss Landing spit was established consisting of a river mouth spit composed of eolian, fluvial, 
estuarine, beach, and near-shore deposits including gravel, sand, silt, and clay (Dupré and Tinsley, 1980).

Unconfined ground water is very shallow ( $<2 \mathrm{~m}$ ) beneath Moss Landing spit and is tidally influenced, at times rising within $1.0 \mathrm{~m}$ of the surface. A fresh water mound of variable thickness overlies the salty ground water (Rutherford \& Chekene, 1988). At the time of the earthquake the ebbing tide was about $0.3 \mathrm{~m}$ above sea level (John Rutherford, personal comm., 1990).

The head of Monterey Canyon is located within $100 \mathrm{~m}$ of Moss Landing spit at a depth of $18 \mathrm{~m}$ (Shepard and Dill, 1966). The canyon head has three branches: the north branch starts directly offshore of the harbor entrance channel; the south branch begins just seaward of the Moss Landing Marine Laboratory (MLML) pier; and the middle branch is located intermediate between the two (Fig. 1).

\section{The Loma Prieta Earthquake}

Seismic shaking at Moss Landing from the Loma Prieta earthquake is a function of distance to the earthquake source, size and duration of the earthquake, and type and thickness of geologic materials underlying the site (Plafker and Galloway, 1989). The epicenter of the Loma Prieta earthquake is located $27.1 \mathrm{~km}$ northwest $\left(\mathrm{N} 18^{\circ} \mathrm{W}\right)$ of Moss Landing (Dietz and Ellsworth, 1990). Woodward-Clyde Consultants (1990) estimated rock site $(0.16 \mathrm{~g})$ and soft site $(0.25 \mathrm{~g}$ [0.2-0.3 g range]) peak horizontal ground motion at Moss Landing. As documented on video tape taken at the time of the earthquake by 
Mr. Edward Heffelfinger and reported by Gardner-Taggart and Barminski (1991), ground shaking at the Moss Landing spit lasted about fifteen seconds. In the vicinity of the earthquake most people felt, and accelerographs registered, about 10-15 seconds of strong ground motion (McNutt and Toppozada, 1990). Typical duration for a Ms=7 earthquake would be 17 to 30 seconds (Dobry et al., 1978). The bilateral nature of the rupture shortened the duration of shaking which mitigated the intensity of the earthquake (McNutt and Toppozada, 1990).

Qualitative data on shaking can be evaluated from observations of earthquake effects on buildings and the ground using the modified Mercalli intensity (MMI) scale (Plafker and Galloway, 1989). A regional assessment by Stover et al. (1990) indicates that Moss Landing experienced MMI VII and the epicentral area experienced MMI VIII during the Loma Prieta earthquake (Fig. 1). The Marina district of San Francisco, which is underlain by unconsolidated sediments similar to Moss Landing, experienced MMI levels of IX, one to two units greater than nearby areas underlain by rock (McNutt and Toppozada, 1990), and coastal areas of Santa Cruz County within $10 \mathrm{~km}$ of Moss Landing experienced MMI levels of VIII (Stover et al., 1990). MMI levels VII and VIII are described by Richter (1958) as:

"VII- Frightened all, general alarm, all ran outdoors. Difficult to stand. Damage to Masonry D (weak materials, such as adobe; poor mortar; low standards of workmanship; weak horizontally) including cracks. Noticed by drivers of automobiles. Hanging objects quiver. Furniture broken. Weak chimneys broken at roof line. Fall of plaster, loose bricks, stones, tiles, comices (also unbraced parapets). Some cracks in Masonry C (Ordinary workmanship and mortar; no extreme weakness, like failing to tie in at corners, but neither nor designed against horizontal forces). Waves on ponds, water turbid with 
mud. Small slides and caving in along sand or gravel banks.

VIII- Fright general, alarm approaches panic. Steering of automobiles affected. Damage to Masonry C; partial collapse. Some damage to Masonry B (Good workmanship and mortar, reinforced, but not designed in detail to resist lateral forces). Twisting, fall of chimneys, factory stacks, monuments, towers, elevated tanks. Frame houses moved on foundations if not bolted down; loose panel walls thrown out. Decayed pilings broken off. Branches broken from trees. Changes in flow or temperature of springs and wells. Cracks in wet ground and on steep slopes."

\section{Earthquake Effects at Moss Landing}

Liquefaction is a process associated with earthquakes whereby ground shaking causes a rapid buildup of pore pressure leading to a loss of soil strength and stiffness. Phenomona caused by liquefaction include sand boils or volcanoes (created when fluidized sand reaches the surface), lateral spreading (the gravitational displacement of liquefied soil towards an unconfined free face or incised slope), and differential settling of structures. Soil liquefaction has been observed in all large earthquakes and the Loma Prieta earthquake produced widespread liquefaction-related ground failure in the Moss Landing area (Plafker and Galloway, 1989). Liquefaction susceptibility maps indicate that Moss Landing has a very high liquefaction potential (Dupré, 1975) and liquefaction induced ground failure during previous earthquakes has been well documented (Youd and Hoose, 1978).

Damage to man-made structures at Moss Landing spit caused by seismic shaking and liquefaction induced ground failure included partial collapse of buildings, buildings moved off foundations, chimneys broken off at roof line, tilted above-ground liquid 
storage tanks, movement of underground storage tanks, tilted and rotated utility poles, cracked and tilted seawalls, pavement rupturing and buckling, broken underground water and sewer pipes, and a broken pipeline offshore (Fig. 2).

The worst structural damage was inflicted on MLML (Fig. 3 A,B) which was the southernmost building on the spit (Fig. 2). The MLML facility was comprised of a 16,000 square foot two-story former cannery built before 1920 and an 11,000 square feet one-story wood-frame addition built in 1982 (Woodward-Clyde Consultants, 1989). Up to 80 centimeters $(\mathrm{cm})$ of lateral spreading and $20 \mathrm{~cm}$ vertical settling occurred beneath the laboratories' site, which rent the buildings and foundations (Brian Kangas-Foulk Inc., 1989). Cracks up to $20 \mathrm{~cm}$ wide split the portion of the 1982 addition underlain by a steel-reinforced concrete shallow-strip footing (Fig. 3B). A shallow six m wide graben with about $40 \mathrm{~cm}$ vertical displacement extended south about $15 \mathrm{~m}$ from the 1982 addition. Horizontal ground movement apparently occurred in a bilateral direction towards the harbor $(40 \mathrm{~cm})$ and towards the ocean $(40 \mathrm{~cm}$ ) (Brian Kangas-Foulk Inc., 1989). In the volleyball court about $6.1 \mathrm{~m}$ south of MLML a large sand boil geysered upwards about $0.6 \mathrm{~m}$ during the earthquake and continued to seep for approximately 45 minutes (M.T. Ledbetter, personal comm., 1989). A portion of the steel-reinforced concrete seawall protecting MLML cracked and settled during the earthquake and subsequently was undermined and failed during the following winter's moderate storms. The west approach to the narrow, one-lane, timber-pile-supported Sandholdt Bridge (Fig. 2) connecting the spit to the mainland settled about $40 \mathrm{~cm}$. General Fish cannery was 


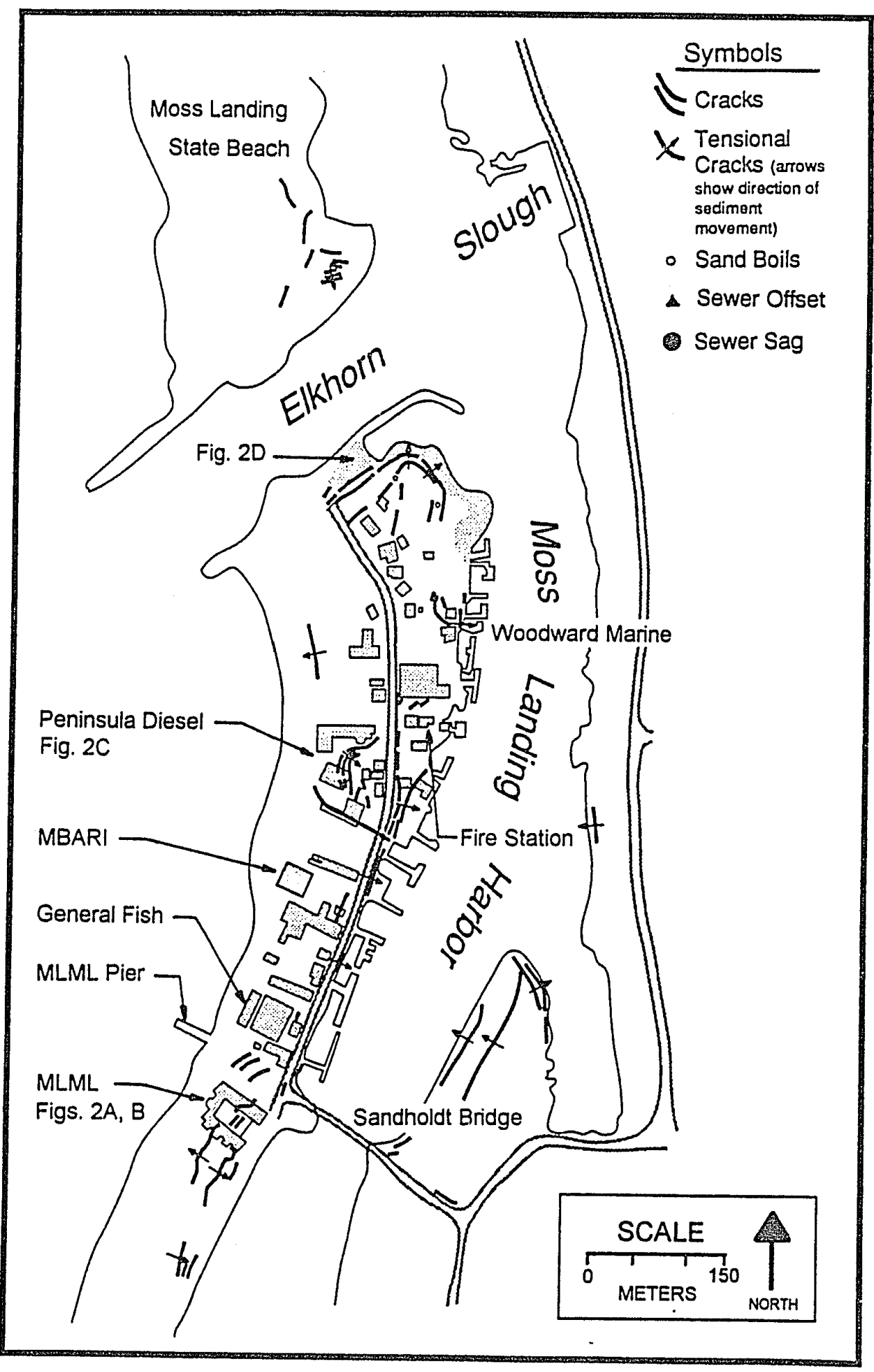

Figure 2: Sketch map of Moss Landing, California, spit and harbor showing surface liquefaction manifestations and sub-surface sewer damage; arrows denote ground cracks and apparent directions of ground failure. 


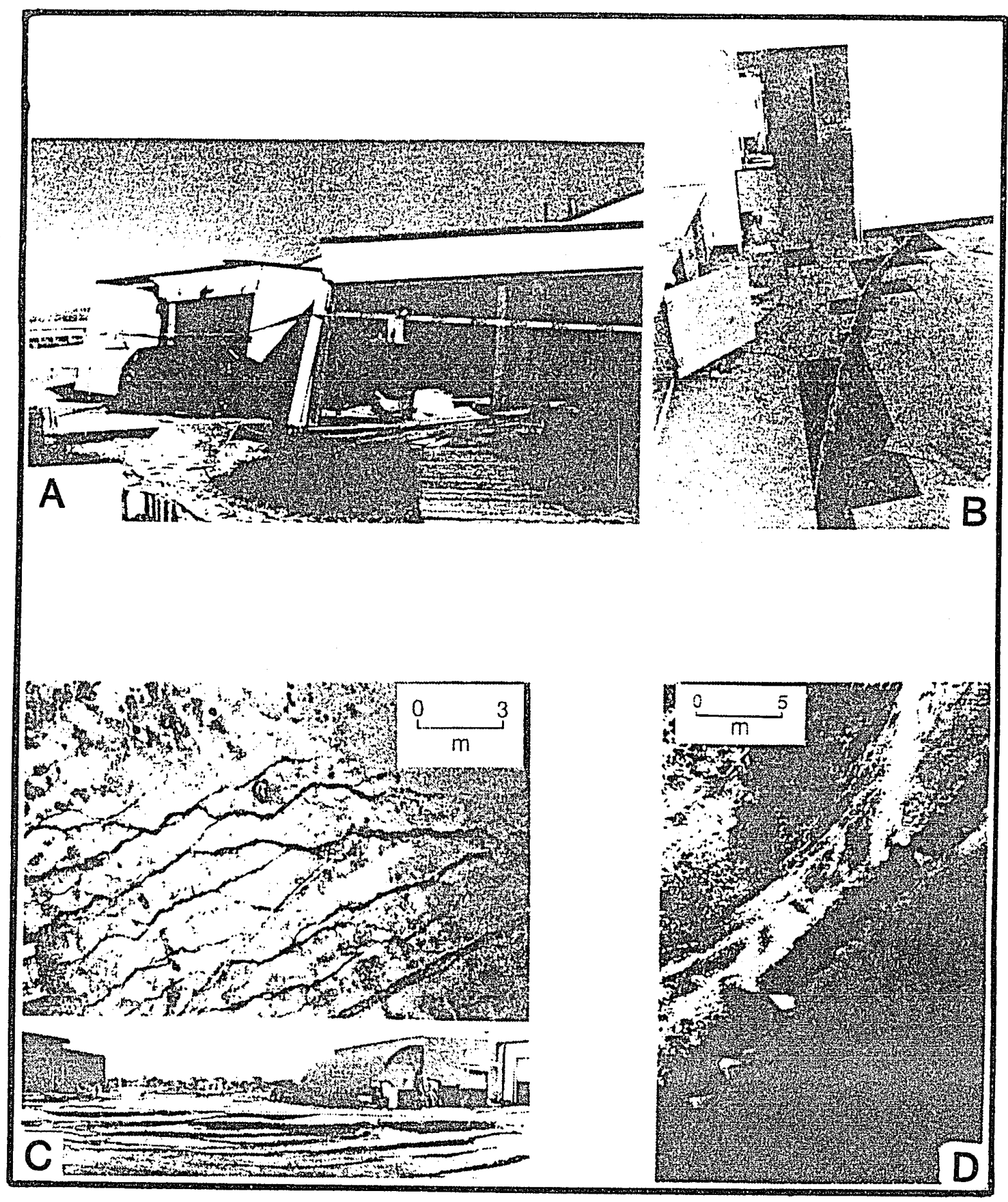

Figure 3: Liquefaction effects on Moss Landing spit (Greene et al., 1991). See Figure 2 for locations of photographs. A: Southwest corner of destroyed MLML building. B: Crack ( $20 \mathrm{~cm}$ wide) in concrete floor of MLML. C: Low-altitude aerial photograph (top) and ground photograph (bottom) of cracks in asphalt at Pacific Diesel Company (Photo by T. Chase, U.S.G.S). D: Graben at north end of spit (Photo by T. Chase, U.S.G.S). 
damaged and subsequently demolished. The concrete foundation and seawall of General Fish was extensively cracked. The modern concrete-lift-slab MBARI (Fig. 2) building suffered little damage (asphalt pavement cracks $<2.5 \mathrm{~cm}$ wide) and no significant settlement (Rutherford \& Chekene, 1989). The old Fire Station, currently MLML Marine Operations building (Fig. 2), settled about $10 \mathrm{~cm}$ (T. Hatano, personal comm., 1991) and the retaining on the harbor shoreline tilted about $5^{\circ}$ east toward the harbor. Woodward Marine (Fig. 2), a marine services facility comprised of three single-story buildings, a short wood-pile pier, and above-ground fuel storage tanks, experienced different degrees of damage. Two modern steel-sided buildings suffered little damage while the 1940's vintage main office was knocked off its concrete perimeter-and-post foundation, wooden pier pilings tilted towards the harbor and a sign pole was toppled. Four above-ground fuel storage tanks tilted $1-6^{\circ}$ due to differential settling (Tuttle et al., 1990). Liquefied material from a sand boil near the tanks consisted of brown, gravelly sand and gray, medium-grained sand to silty sand and liquefaction dikes from a sand boil were traced downward to a depth of $84 \mathrm{~cm}$ below the surface (Tuttle et al., 1990). During the earthquake a ground crack about $15 \mathrm{~cm}$ wide opened up between the feet of a local fisherman and water spouted vertically from the crack at Woodward Marine. Another small crack formed parallel to the shoreline along the boundary of artificial fill (Foxx, Nielson and Associates, 1990).

Post-earthquake levelling surveys determined the amount of differential settling on the spit (Greene et al., 1991). Comparison of finished floor elevations with actual 
post-earthquake measurements indicated that approximately $30 \mathrm{~cm}$ of subsidence occurred at MLML (Greene et al., 1991). About $102 \mathrm{~m}$ north of MLML a sewer lift station settled about $10 \mathrm{~cm}$ (Griggs, 1990).

\section{Previous Earthquakes}

Four historical earthquakes of M 7 or greater $(1838,1865,1906,1989)$ have occurred in the Monterey Bay region, more than found in almost any other area in California. 1865 and 1989 earthquake intensities (MMI VII) for Moss Landing are comparable (McNutt and Toppozada, 1990). Moss Landing experienced MMI VII+ and liquefaction from the 1926 M 6.1 earthquakes, which occurred about $15 \mathrm{~km}$ offshore on the Monterey Bay fault zone (Greene, 1977). The 1906 -M 8 San Francisco earthquake generated the highest historical earthquake intensity [MMI VIII or IX (Richter, 1958)] at Moss Landing (McCrory et al. 1977). Locations of ground failure resulting from soil liquefaction during the Loma Prieta earthquake were coincident with similar areas of ground failure during the 1906 earthquake; fourteen of eighteen areas that liquefied in the 1906 earthquake experienced liquefaction during the 1989 earthquake (W.R. Dupré and J.R. Tinsley, personal comm., 1990). Liquefaction occurred around the margin and interior of Monterey Bay from Santa Cruz to Salinas in both late Holocene and active flood-plain deposits of the San Lorenzo, Pajaro, and Salinas river valleys and in spits, bars, and tidal channels of smaller coastal drainages (Greene et al., 1991). Damage resulting from the 1906 earthquake was more severe at Moss Landing than any other 
reported earthquake (Fig. 4).

A Salinas newspaper reported that: "Moss Landing has been practically wiped off the map. The long wharf [present-day MLML pier] and the Pacific Steamship Company's big warehouses [1989 MLML site] collapsed and are flat. From reports that come in from that locality the waves are running quite high and are breaking the wharf to pieces and are carrying away timbers." (Salinas Weekly Index, 1906).

Lawson (1908) reported that: "At Moss Landing many small cracks occur in the mud on the west side of the river, and the condition of the wharf indicates an eastward movement of the sand-spit. It is reported that at places along the pier where the water was formerly 6 feet $[1.8 \mathrm{~m}]$ deep, it now has a depth of 18 or 20 feet [5.5 to $6.1 \mathrm{~m}]$. North of Moss Landing the ground settled nearly 2 feet $[0.6 \mathrm{~m}]$ in places, as shown by marks on railway piles at several crossings and by sagging of the track in several other places."

Lawson (1908) also notes: "Along the beach or sand-spit which separates the Salinas River from the Bay of Monterey at Moss Landing, there is a marked lurching of the spit toward the trench of the river." A "house, tree, and fence moved 12 feet $[3.7 \mathrm{~m}]$ by ground lurching toward the Salinas River." "At Moss Landing where the river runs parallel with the shoreline, the strip of land is seamed for miles. A crack or rather a sink, about 20 feet $[6.1 \mathrm{~m}]$ wide and 4 or 5 feet $[1.2$ or $1.5 \mathrm{~m}]$ deep ran under the buildings and rent them asunder. The office building between this crack and the river has moved bodily-land and all-about 12 feet $[3.7 \mathrm{~m}]$ toward the river. Some of the cracks run into the ocean." 


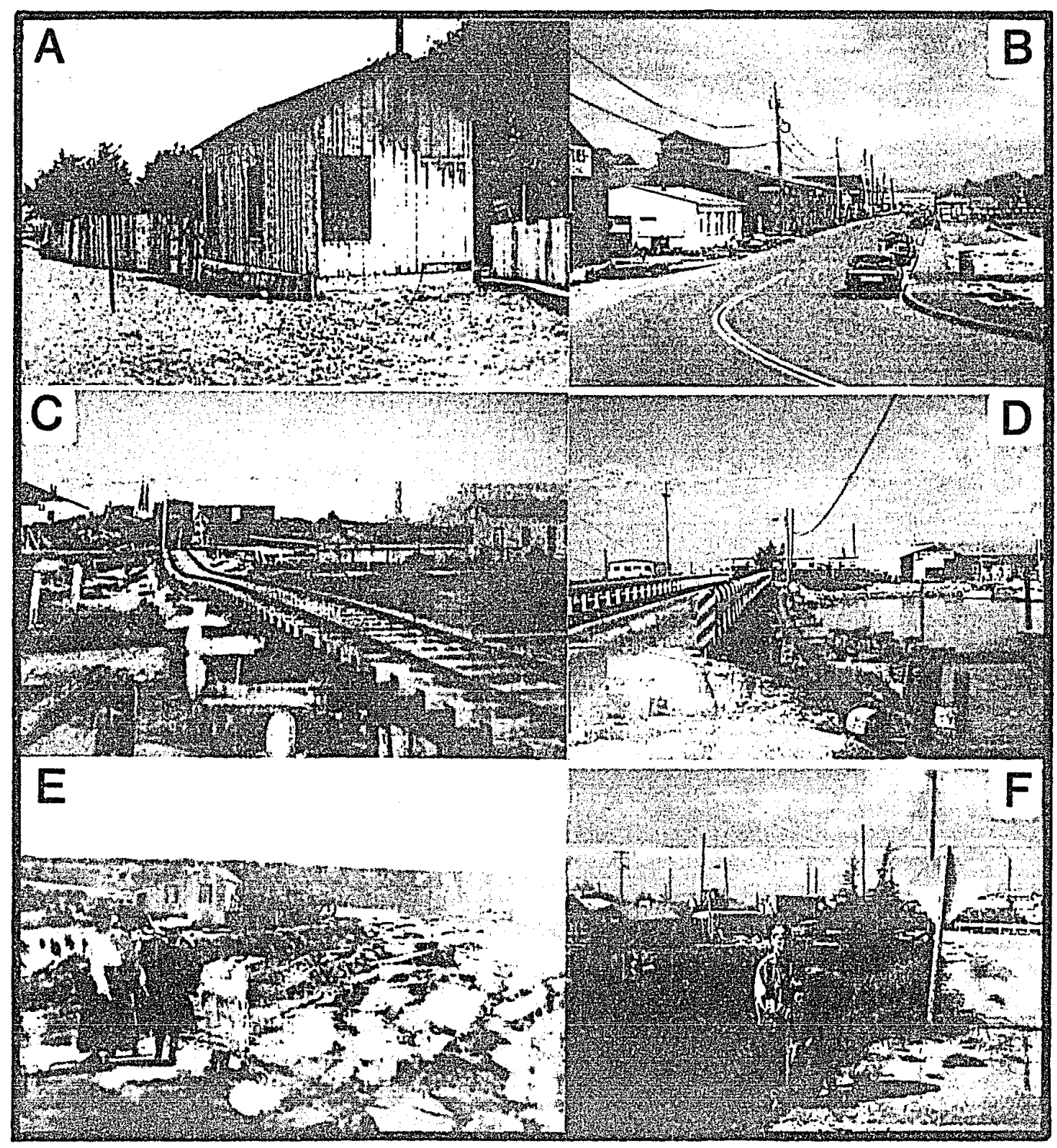

Figure 4 A,B,C,D,E,F: Comparison of 1906 and 1989 earthquake damage. A: During 1906 earthquake house, tree and fence moved $3.7 \mathrm{~m}$ toward Salinas River (Lawson et al., 1908). B: During 1989 earthquake $<30 \mathrm{~cm}$ of ground deflection occurred at same location shown in Fig. 4A. C: During 1906 earthquake lateral spreading caused bridge to collapse. Warehouse and pier in background (1989 MLML) were also destroyed. D: During 1989 earthquake the Sandholdt Road western bridge abutment settled $40 \mathrm{~cm}$. MLML was destroyed. E: During 1906 earthquake extensive liquefaction occurred on roadway crossing Moro Cojo Slough (Lawson et al., 1908). F: During 1989 earthquake about 5.1 $\mathrm{cm}$ of lateral spreading occurred on margins of roadway crossing Moro Cojo Slough. 


\section{Historical Shorelines}

Changes in ocean and harbor shorelines of Moss Landing spit are delineated on three U.S. Coast and Geodetic Survey charts from 1854, 1910, and 1933 (Fig. 5). These charts indicate that prior to 1910 the Salinas River flowed parallel to the ocean shoreline through Moss Landing and entered the ocean well north of the present harbor entrance. Elkhorn and Moro Cojo sloughs also discharged into the ocean at the same location. In 1910 the Salinas River breached the sand dunes several miles south of Moss Landing and has since flowed into Monterey Bay there (Gordon, 1987). Elkhorn and Moro Cojo sloughs have exited to the ocean at the Moss Landing harbor entrance since the harbor was built in the 1940's. Construction of the harbor created new land behind the harbor jetty at the north end of the spit as well as northeast of Sandholdt Bridge (Fig. 2). Although some shoreline change has occurred as a result of the natural and artificial alterations described above, evidence from historical maps indicate that relatively little overall beach shoreline change has occurred in the vicinity of MLML over the past 139 years (Griggs, 1990). The old Salinas River or harbor shoreline north of MLML has changed more over the same period of time partially because of artificial fill placement along the harbor margins. 


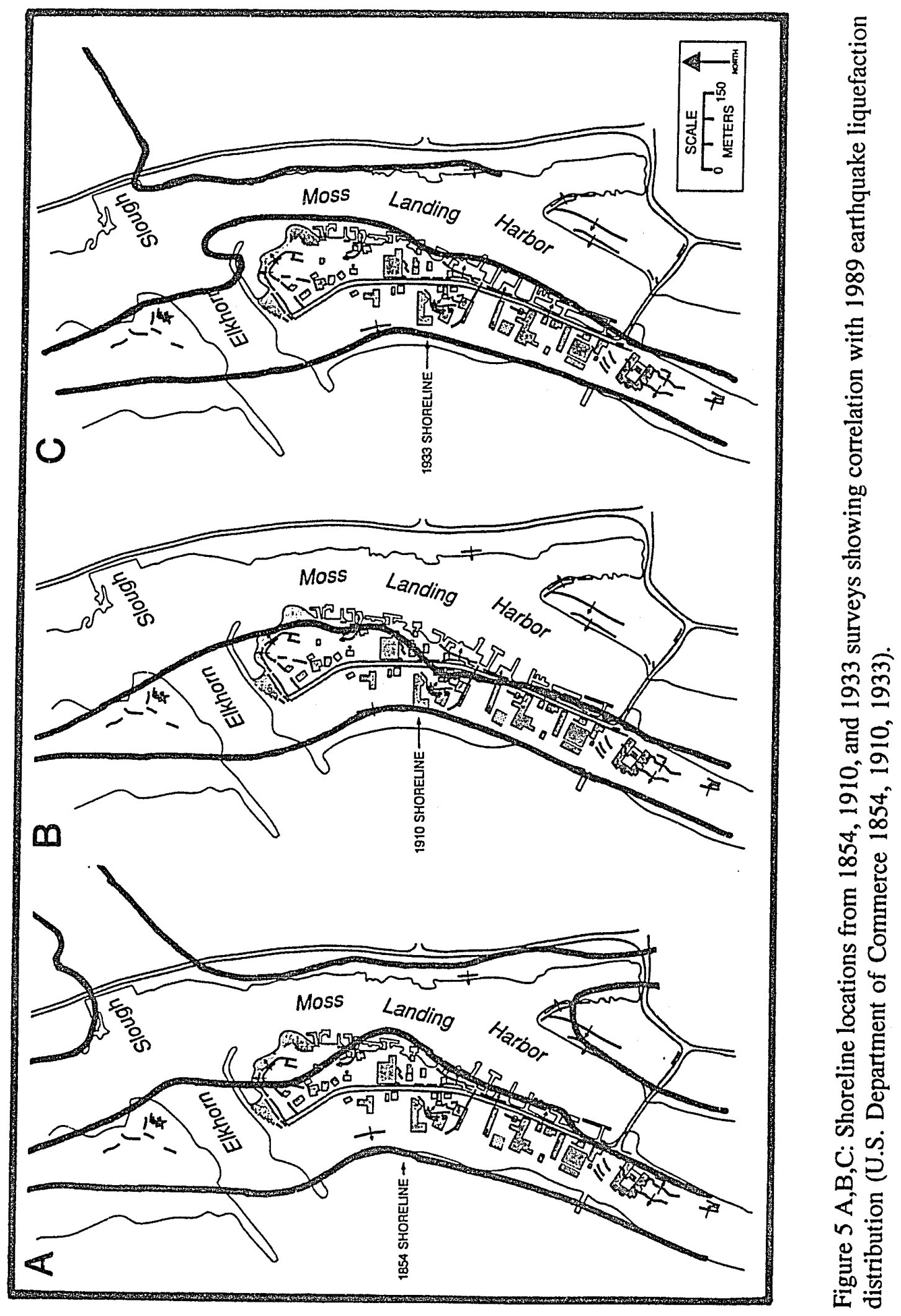




\section{Offshore Effects}

Within ten days of the earthquake, geophysical data including side-scan sonographs were collected offshore from Moss Landing spit by MLML researchers on the R/V Point Sur (Greene et al., 1991). Sonographs along north-south-trending tracks oriented parallel to the Moss Landing spit indicate several curvilinear liquefaction features oriented generally northeast-southwest (Fig. 1) that trend subparallel to the ship's track. These features, which were observed in water depths of 9-12 $\mathrm{m}$, had lobate to serrate fronts, with irregular, hummucky surfaces landward of the fronts. Greene et al. (1991) describe a well-defined, west facing scarp along one trackline west of MLML, and offshore of this scarp an irregular, hummocky surface was imaged that appeared to contain sand boils. The authors further state that the lobate and serrate liquefaction fronts were all restricted seaward of the scarp. This scarp, oriented northeast-southwest, appeared to parallel cracks mapped on the spit north of MLML. Fathometer records collected along tracklines perpendicular to the spit indicate a stair-step pattern of scarps that parallel liquefaction fronts. These scarps are 3-6 $\mathrm{m}$ high and at least $100 \mathrm{~m}$ long. SCUBA diver observations made several days after the earthquake also located these scarps but no evidence of the scarps remained two months after the earthquake, due to strong winds and rough seas (Tom Okey, personal comm., 1990).

Several submarine slumps have been mapped near MLML in the headward part of Monterey Canyon, where canyon walls are composed of Pleistocene and Holocene unconsolidated eolian, fluvial, and deltaic deposits (Greene, 1977). The largest slumps, 
are along the north wall of the canyon and appear to have been caused by failure of a Pleistocene river channel that was exposed during erosion of the canyon (Greene, 1977). Uniboom and side-scan profiles collected in this region after the Loma Prieta earthquake indicate no new movement, suggesting that slumps here are stabilized and would require earthquakes larger than the Loma Prieta earthquake to stimulate movement (Greene et al., 1991). The south wall of the canyon is formed primarily of deltaic deposits from the Salinas River, and fresh slump scarps up to $6.3 \mathrm{~m}$ high were detected using MBARI's ROV Ventana (Greene et al., 1991). Recent formation of these scarps was evident by freshly exposed benthic worm tubes and a high concentration of starfish, crabs, and other bottom dwellers feeding on the newly exposed benthic fauna (Greene et al., 1991). March, 1991 dives, using the ROV Ventana videotaped large slabs of mud ( 6 by $10 \mathrm{~m}$ ) in the canyon axis which apparently broke off from the upper part of the south canyon wall and slid into their present position, and a March, 1991 fathometer survey aboard the $\mathrm{R} / \mathrm{V}$ Point Sur replicated a pre-earthquake traverse in the canyon head region and found that $\sim 30 \mathrm{~m}$ of canyon infilling had occurred since the last survey (Greene et al., 1991). 


\section{METHODS}

Several research techniques were applied in the study area both onshore and offshore. Data used in this study consists of real-time observations, post earthquake mapping and categorization of onshore ground cracks and building damage, leveling, geotechnical boring information, downhole seismic shear wave surveying, and offshore geophysical and video surveying.

\section{Mapping}

Within one week following the 1989 earthquake attention was focused on documentation and reconnaissance mapping of ephemeral earthquake related surface effects and building damage (Figs. 1,2). Low altitude aerial photographs were obtained using a blimp-mounted remote operated camera system constructed and operated by Tom Chase of the U.S. Geological Survey (Figs. 3C, 3D). Field measurements of surface cracks and fissures were made with tape and compass to supplement photographic and video data. Leveling data was acquired with a total-station theodolite (Greene et al., 1991). A post-earthquake videotape of sewer line damage was viewed and damage locations were plotted (Green Line Underground Video, 1989).

\section{Borings}

Seven soil borings were drilled to depths up to $15 \mathrm{~m}$ below the surface by either 
rotary-wash or hollow-stem-auger truck-mounted drill rigs at Woodward Marine, and the Fire Station (Fig. 6), (M. Jacobs \& Associates, 1990, 1991). Soils encountered during drilling were logged continuously and classified according to the Unified Soil Classification System (U.S. Department of Interior, 1986). Soil samples were collected using either a $5.05 \mathrm{~cm}$ or $7.62 \mathrm{~cm}$ outer diameter modified split barrel sampler with internal liners. Standard Penetration Test (SPT) procedures were followed; for each test the sampler was seated $15.24 \mathrm{~cm}$ into the soil, then the number of blows required to drive the sampler the next $0.2 \mathrm{~m}$ was recorded as the field penetration value (Youd and Bennett, 1983). Field penetration values assist in determining the strength characteristics of soils and were normalized to SPT-N (normal) values. The sampler was driven by a 63.5 kg Mobile "In-Hole Sampling Hammer" that was lifted and then dropped a vertical height of $0.51 \mathrm{~m}$ with a Mobile "Safe-T-Driver hoist". Calibrated efficiency of the hammer is $68 \%$ of an ideal freefall hammer (Seed et al., 1985). Water content, grainsize distribution, and Atterburg limits were determined in the laboratory using the appropriate American Standard of Testing and Materials method.

Numerous boring logs from other earlier investigations (Fig. 6) were examined and correlated for the purpose of constructing geologic cross-sections. These borings were located: in the vicinity of MLML (Jo Crosby \& Associates, 1981; Cooper-Clark \& Associates, 1978; Woodward-Clyde \& Associates, 1990), near MBARI (Harding Lawson Associates, 1988, 1990; Rutherford \& Chekene, 1987, 1988), at Woodward Marine (FoxxNielson, 1990), and along an east-west transect from the harbor to the bay (Dames \& 

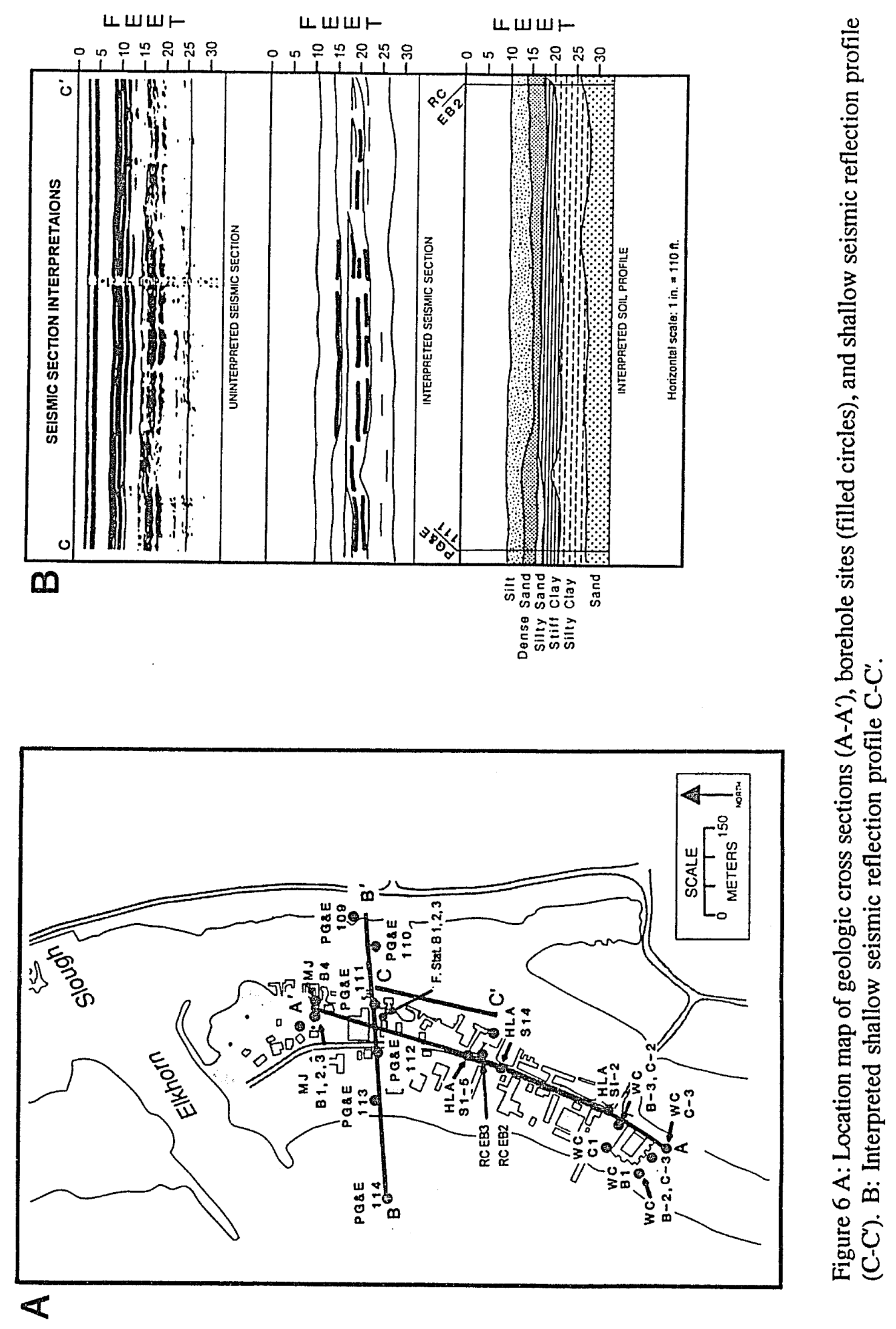


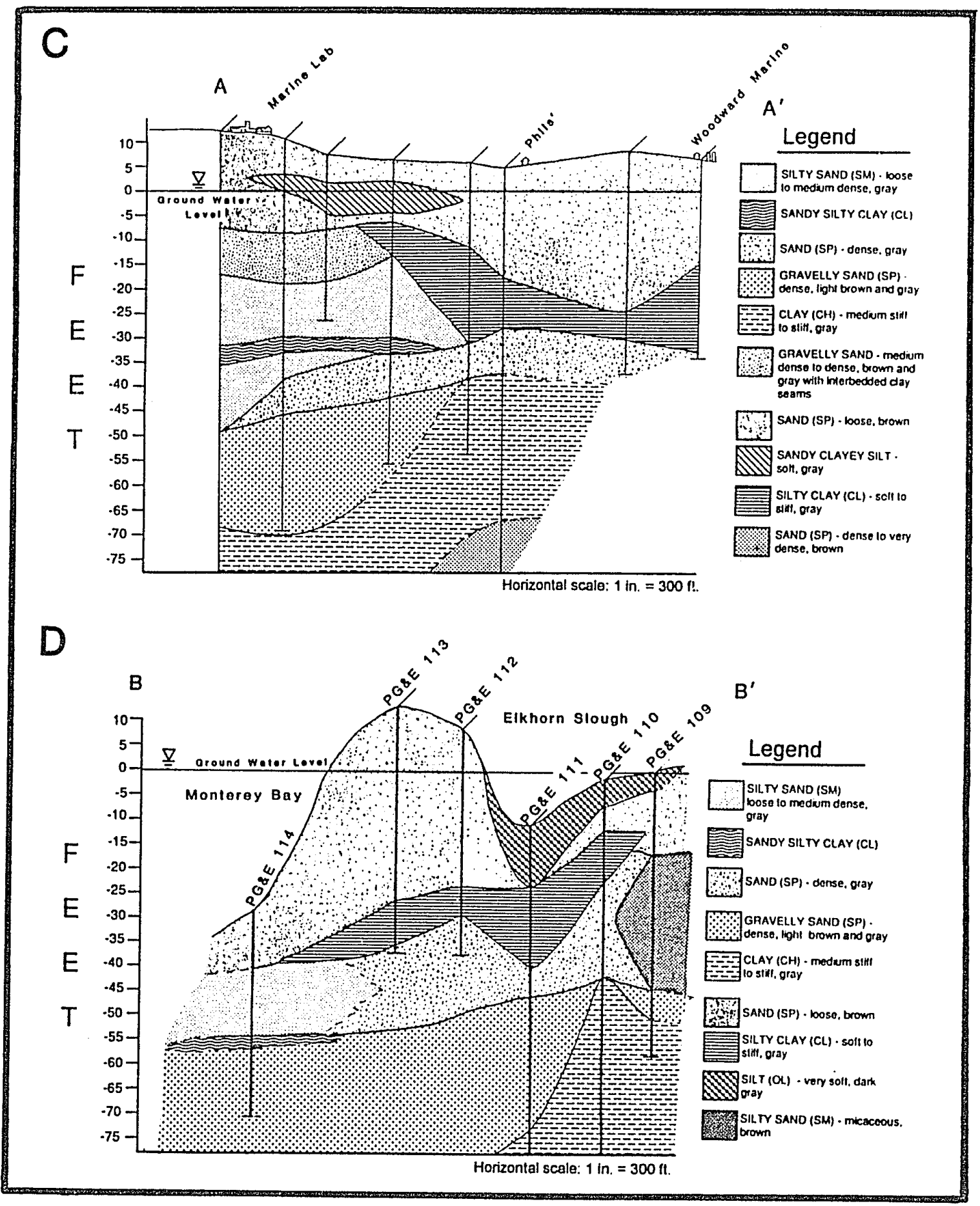

Figure 6 C: North-south geologic cross-section A-A'. D: East-west geologic cross-section B-B'. Locations on Fig. 6A. 
Moore, 1963). Geologic interpretation was based on similarities in physical characteristics.

Field data were analyzed for liquefaction potential using a computer program based on Seed and Idriss (1982) (Blake and Blake, 1987). Results from SPT tests on the spit and laboratory-derived particle size distribution from soil samples collected during drilling were used to estimate liquefaction resistance. According to Seed and Idriss (1982), a normalized penetration resistance can be used directly for an index of liquefaction resistance rather than first estimating relative density. The blow count correction factor accounts for effective overburden stress. Single SPT-N blow counts obtained under precisely controlled field and laboratory conditions have a maximum spread of $30 \%( \pm 15 \%)$ in relative density (Marcuson and Bieganousky, 1977), which is about the same as the spread in values obtained for the direct determination of relative density itself. Ground water elevation equal to mean sea level was used in the analysis. Soil profiles chosen for analysis were in the vicinity of MLML, General Fish, MBARI, Fire Station, and Woodward Marine (Figs. 2, 6). Estimated liquefaction resistance was then compared with the estimated Loma Prieta earthquake induced cyclic stress ratio using an assumed horizontal ground acceleration of $0.25 \mathrm{~g}$ (Woodward-Clyde Consultants, 1990) to arrive at a factor of safety against liquefaction for each soil profile. Factor of safety values $<1$ indicate liquefaction will occur. 


\section{Geophysical Surveys}

Inclinometer or slope indicator casing $(8.48 \mathrm{~cm}$ diameter) was installed along Sandholdt Road on the harbor side of the spit prior to the Loma Prieta earthquake (March, 1989) as part of a bulkhead construction program by Harding Lawson Associates (1990), (HLA S4,5, see Fig. 6). Inclinometer casing was installed at the Fire Station (F. Stat. B2, see Fig. 6) after the earthquake (M. Jacobs \& Associates, 1991). The inclinometer casing was used for measuring the amount of horizontal deflection in the soil by means of an inclinometer and conducting a down-hole shear wave study. Shear waves were generated by horizontal blows of a $7.26 \mathrm{~kg}$ sledgehammer against the ends of a wooden plank held in contact with the ground surface by the front wheels of an automobile. All of the holes were lined with slope indicator casing to maintain the downhole transducer at a fixed azimuth to the borehole, thus facilitating field measurements and improving the quality of records by allowing the geophone to be aligned with the shear wave source. Downhole signals were detected by a horizontal geophone mounted on a slope indicator wheel assembly and mechanically locked to the casing at the desired depth by means of a rubber bladder inflated with nitrogen. Signals were recorded on an Oyo-Nimbus ES 120012 channel digital seismograph. At each measurement point, shear waves with positive and negative polarities were generated by a hammer blow at each end of the plank. The two shear wave signals were then superimposed on the paper recording. The point at which the recorded traces diverge generally marks the onset or arrival of the shear wave (Redpath, 1991). Arrival time of the shear waves was used to calculate shear wave 
velocities which correlate to liquefaction resistance (Tokimatsu and Ushida, 1990) and are directly related to soil characteristics such as soil type and SPT values (Bailey and Van Alstine, 1975).

\section{Offshore Surveys}

Four separate cruises were taken aboard the R/V Point Sur and R/V Ed Ricketts after the earthquake to identify offshore earthquake effects. Offshore geophysical data on the R/V Point Sur were collected with an EG\&G digital side-scan system supplied by the U.S. Geological Survey and a Uniboom high resolution seismic reflection system in the canyon head and nearshore areas (Fig. 1). Navigation was by Mini-Ranger; onboard receivers were supplied by the Naval Postgraduate Graduate School in Monterey. Offshore geophysical data on the R/V Ed Ricketts were collected in the shallow $(<25 \mathrm{~m}$ ) area less than $300 \mathrm{~m}$ offshore from MLML with a fathometer, navigation was by Loran $\mathrm{C}$ and radar. Data were analyzed from a north-south seismic reflection survey of paleoriver channels conducted from small boats ( $3.7 \mathrm{~m}$ length) in Moss Landing harbor (M.T. Ledbetter, personal comm., 1991). See Fig. 6A and B for location of seismic reflection profile. Information was used from underwater SCUBA reconnaissance conducted by John Oliver and Tom Okey of MLML in the canyon head area less than $200 \mathrm{~m}$ offshore of MLML. 


\section{RESULTS}

Drilling and correlation with available boring logs indicates that the spit is uniformly underlain by loose, fine to medium grained, well-sorted dune sand (Fig. $6 \mathrm{~B}, \mathrm{C}, \mathrm{D})$. This sand typically extends to about three $\mathrm{m}$ below ground level and can be saturated at one $\mathrm{m}$ or less below ground level depending on tidal fluctuation. Sediment types vary, but generally found below the dune sand is a medium to very coarse grained sand containing numerous shells and shell fragments derived from a high-energy marine environment. This sand is underlain at 2.1 to $4.6 \mathrm{~m}$ below sea level by a dark, grayish green silt or clay of estuarine origin. The north-south geologic cross-section (Fig. 6C) indicates that the silt or clay is absent at the south end of the spit near MLML.

The shallow loose sand has a very high liquefaction potential and a calculated liquefaction safety factor ranging from 0.21 to 0.68 (Fig. 7). Similar liquefiable material extends to a maximum depth of $8.5 \mathrm{~m}$ below the surface. The lowest potential for liquefaction occurs in the vicinity of MBARI (0.68) and the greatest potential occurs at the south and north ends of the spit in the vicinity of MLML (0.51) and Woodward Marine (0.21). The greatest thickness of liquefiable material is in the vicinity of MLML $(4.1 \mathrm{~m})$. Examination of extruded sand boil material and calculations indicate finegrained sediments such as silts and clays did not liquefy during the earthquake. Sands below the silts and clays are not liquefiable. Extruded sand boil material consists of gray sand or silty sand similar to sand found at depths from $<1.0 \mathrm{~m}$ (Tuttle et al., 1990) to 

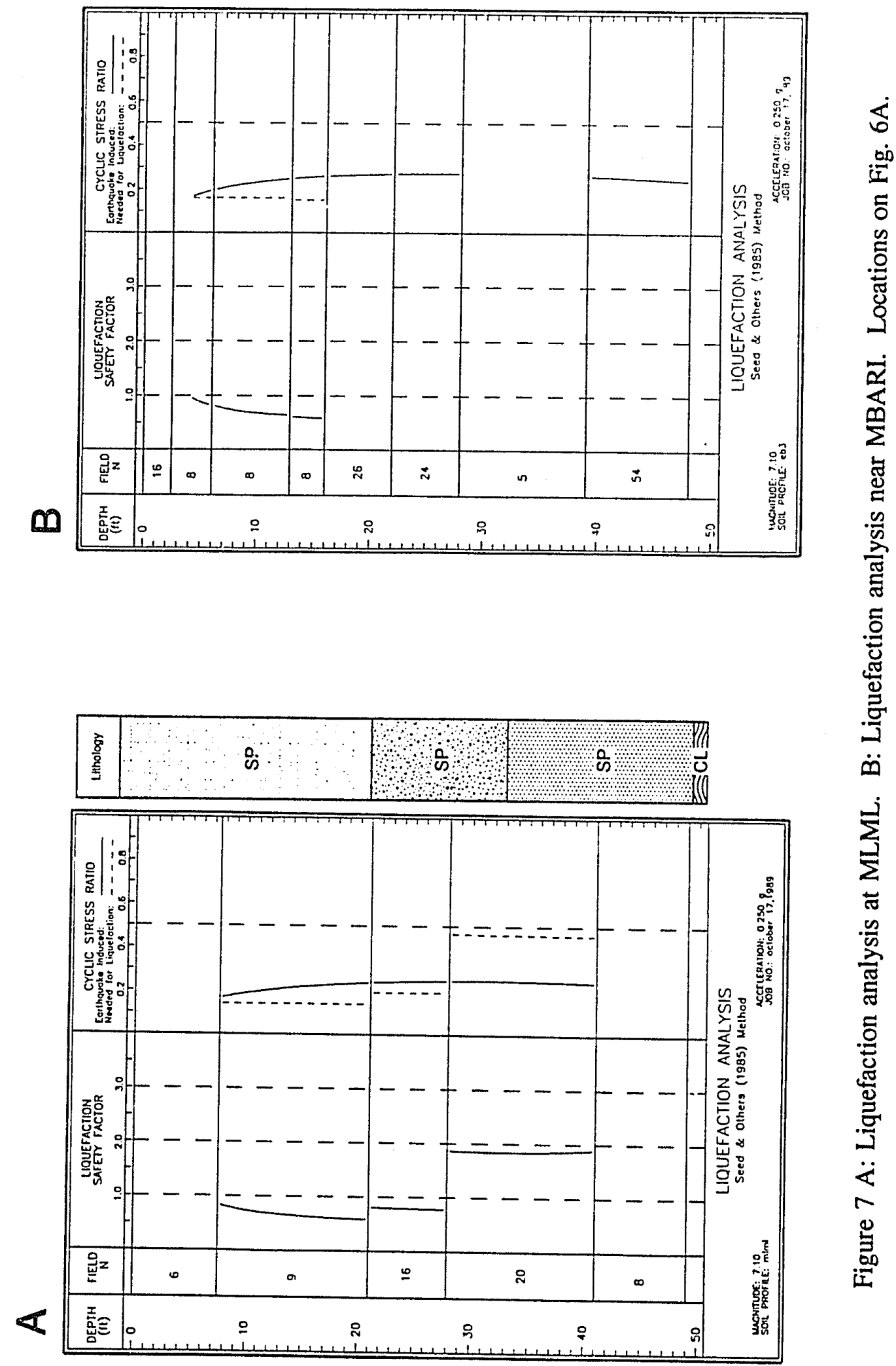


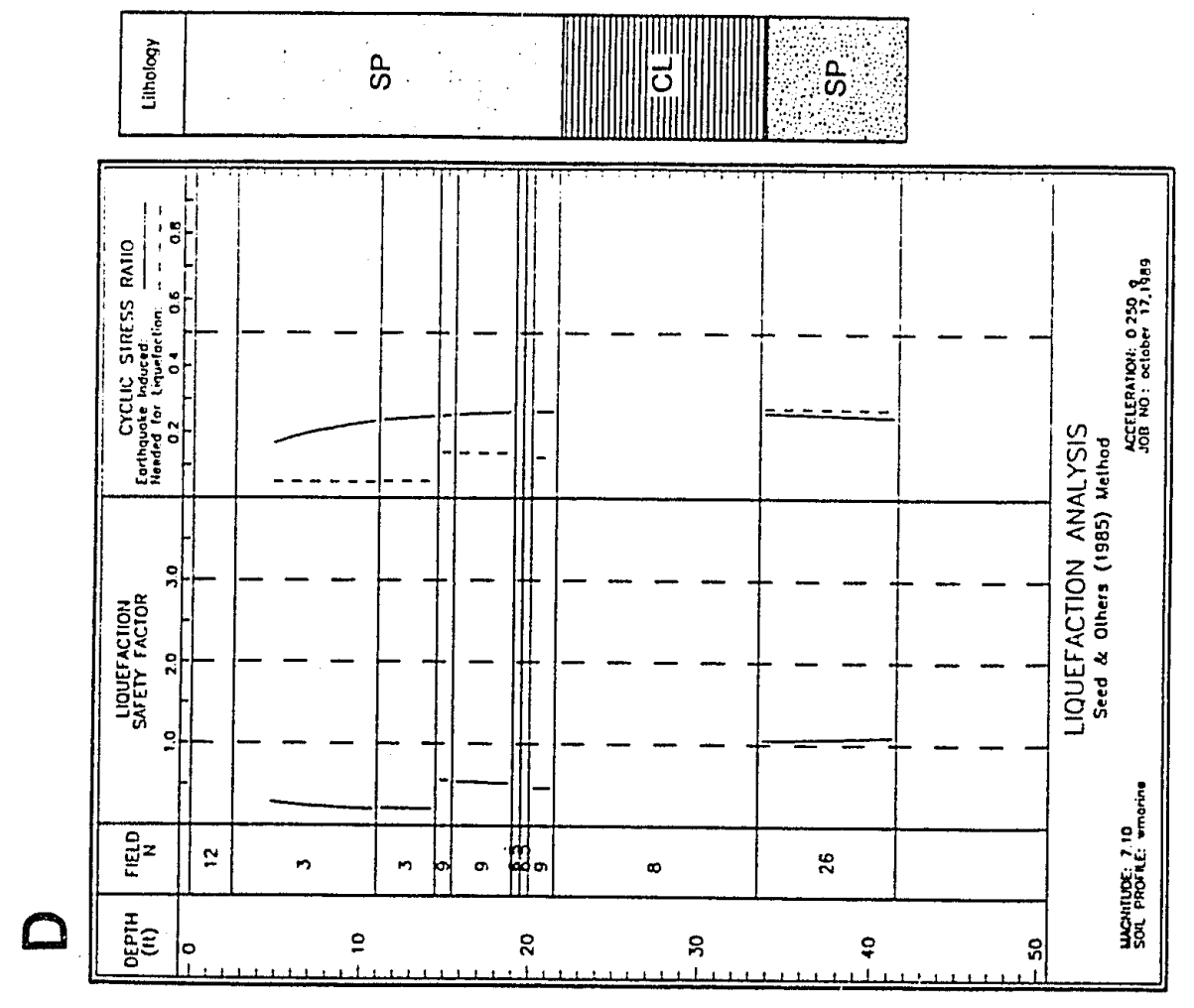

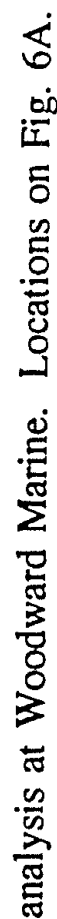

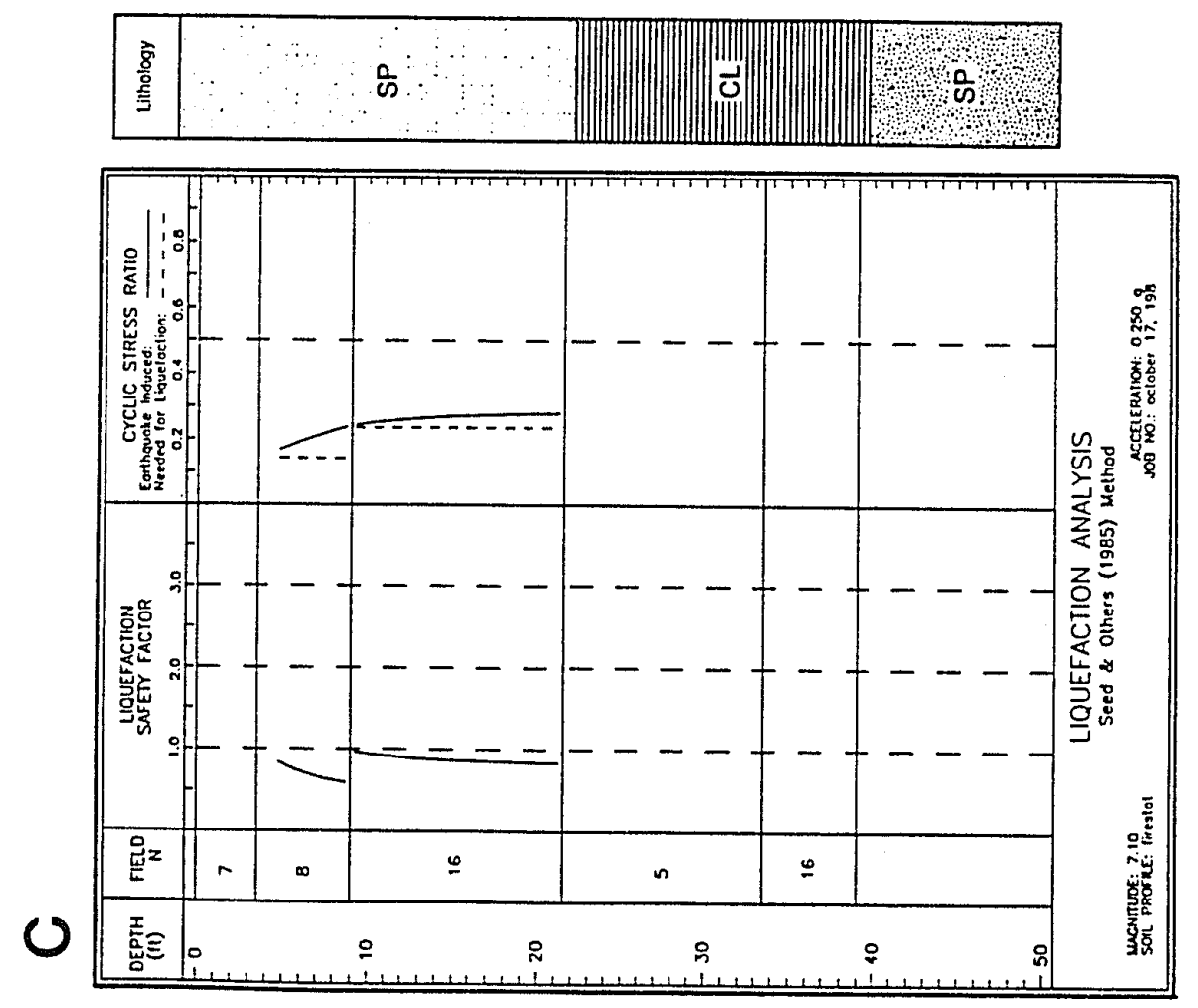


$6.1 \mathrm{~m}$ from a saturated reducing environment (Borchardt, 1991).

Post earthquake mapping indicates that liquefaction effects are not distributed evenly on the spit. The area of moderate and severe liquefaction characterized by sand boils, ground settlement $>2 \%$ of stratum thickness, or heavy structures settling more than $20 \mathrm{~cm}$, (Tokimatsu and Yoshimi, 1983) encompassed MLML, the Fire Station, Woodward Marine and the northeast end of the spit (Fig. 3). Sand boils were noted from near the Fire Station north to the harbor entrance and around MLML. The most extensive area ( 40 by $50 \mathrm{~m}$ ) of sand boils was located at the northeast end of the spit and contained numerous coalescing and distinct sand boils.

Two predominant types of ground cracks were observed during post earthquake field mapping. The first type were extensional liquefaction or lateral spreading cracks which generally paralleled topographic features such as shoreline banks (Fig. 2, 3D) and/or correlated with historic shorelines and artificial fill boundaries (Fig. 5). Long linear liquefaction cracks (2.5-5 cm wide); (prominent cracks shown on Fig. 2) paralleled the harbor shoreline the entire length of the spit. Very few lateral spreading cracks were found on the ocean side of Moss Landing spit. A $4.5 \mathrm{~m}$ wide and $120 \mathrm{~m}$ long graben with $40 \mathrm{~cm}$ of vertical offset formed at the far north end of the spit parallel to a $1.8 \mathrm{~m}$ high shoreline bluff (Figs. 2, 3D). Minor soil fall debris ( 0.5 by $0.75 \mathrm{~m}$ ) was found at the base of this bluff after the earthquake. Extensive ground cracking complexes with spider web patterns, stair-step vertical offsets, with extruded gray sand encompassed MLML, the Fire Station, Peninsula Diesel (Fig. 3C), Woodward Marine, and the far 
northeast end of the spit (Fig. 3D). The second type of cracks were compressional in nature and were restricted to brittle surfaces such as asphalt or concrete and were aligned in an east/west direction. Compressional cracks were located predominantly north of Woodward Marine and in the vicinity of MLML on the spit. On a $150 \mathrm{~m}$ long, fairly straight segment of asphalt road at Moss Landing State Beach (Fig. 2) compressional cracks were irregularly spaced at 12 to $38 \mathrm{~m}$ intervals.

Damage contrasted greatly at two newer ( $<10$ years old) engineered structures on Moss Landing spit; MLML was essentially destroyed and MBARI suffered little or no damage. Most of the other buildings damaged on Moss Landing spit were 25 to 75 year old unengineered structures, vulnerable to earthquake damage. Sewer line breaks were unevenly distributed on the spit with most of the breaks confined to the north and south end of the spit (Fig. 2). Comparison of contemporaneous earthquake photographs and descriptions indicate that 1906 earthquake horizontal ground movements were twelve times greater, and vertical ground movements were three times greater than the 1989 earthquake (Lawson, 1908).

Comparison of Harding Lawson Associates' (1990) June 14, 1989 probe inclinometer readings with post-earthquake (Nov. 30, 1989) readings, indicates that slope deflections were greatest in the easterly direction towards the harbor $(27 \mathrm{~cm})$, with lesser slope deflections toward the south $(12 \mathrm{~cm}$ ) (Fig. 8). The greatest amount of deflection occurred in the upper six meters of the borings primarily in the dune sand deposits. A lesser amount of slope movement occurred in the lower silty sands and clays. 


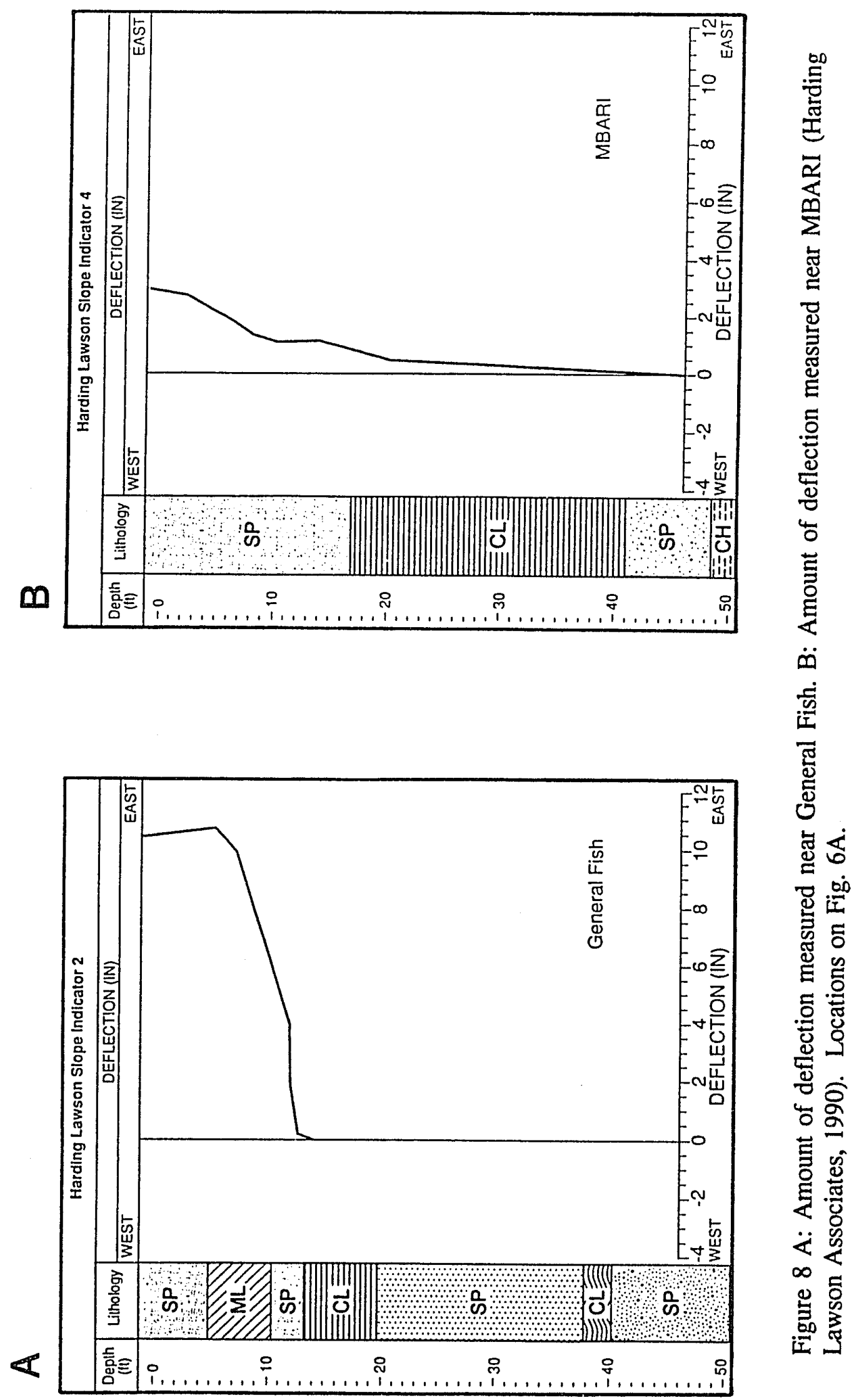


The slope indicator near General Fish (Fig. 8A) registered the greatest amount of deflection $(27 \mathrm{~cm}$ ) while the slope indicator nearest MBARI (Fig. 8B) registered the least $(7.1 \mathrm{~cm})$.

Three distinct shear wave velocities which increased with depth were defined by down-hole shear wave surveys at two locations. Fire Station shear wave velocities were $146 \mathrm{~m} / \mathrm{s}$ in the uppermost loose sand from the surface to $6.1 \mathrm{~m}$ below the surface, 178 $\mathrm{m} / \mathrm{s}$ in silt and dense sand from 6.1-15.2 $\mathrm{m}$ below the surface, and $264 \mathrm{~m} / \mathrm{s}$ in dense sand and silt from 15.2-18.3 $\mathrm{m}$ below the surface (Fig. 9). General Fish shear wave velocities were $146 \mathrm{~m} / \mathrm{s}$ in the uppermost loose sand and sandy silt from the surface to $4.3 \mathrm{~m}$ below the surface, $186 \mathrm{~m} / \mathrm{s}$ in silty clay and loose to medium dense silty sand from 4.3-12.2 m below the surface, and $283 \mathrm{~m} / \mathrm{s}$ in sandy clay, dense sand, and dense gravelly sand from 12.2-18.3 $\mathrm{m}$ below the surface (Fig. 9). 


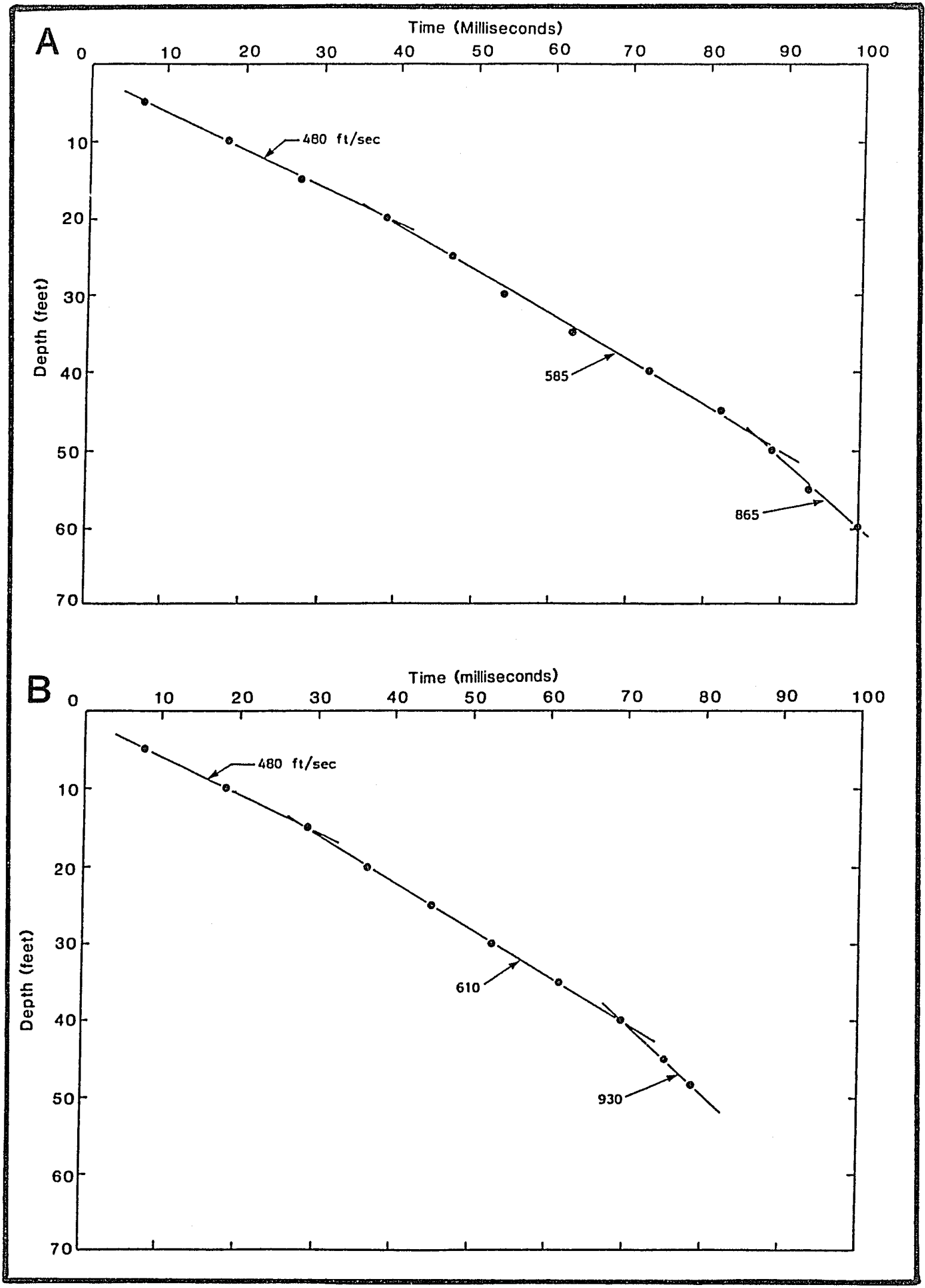

Figure 9 A: Travel times of shear waves vs. depth; Fire Station. B: Travel times of shear waves vs. depth; General Fish. Locations on Fig. 6A. 


\section{DISCUSSION}

Results suggest that the differing degrees of building damage and uneven distribution of liquefaction effects documented at Moss Landing spit after the Loma Prieta earthquake should be interpreted by considering variations found in sediment type, distribution and age of sediment, liquefaction potential and thickness of liquefiable sediments, proximity to free faces at the head of Monterey Canyon and along bluffs at the shoreline of the harbor, and building design and construction (Table 1).

\section{Liquefaction}

Past liquefaction analyses indicate that geologic factors are an important variable in determining liquefaction behavior. The Holocene age sedimentary sequence at Moss Landing is comprised of a transgressive sequence with fine grained slough materials being progressively overlain by river, beach, and dune deposits. The coarse grained sediments derived from the river and beach environments, which are most prone to liquefaction are at and near the surface. Geologic cross sections indicate a variability in the thickness of coarse sediments (Fig. 5). Sediment size gradation curves of the river and beach sand and gravelly sand, and of the overlying dune sand lie within the liquefaction sensitive envelope of gradation curves from the 1964 Niigata, Japan earthquake (Seed and Idriss, 1982).

Liquefaction analyses were performed in five locations and results were consistent 
with the observed surface liquefaction severity. Thickness of the liquefiable soil layer may also have affected the liquefaction severity. Liquefaction severity was greatest at MLML and Woodward Marine. The lowest liquefaction safety factor (0.21) is at Woodward Marine which has a $5.2 \mathrm{~m}$ thick liquefiable soil horizon. Liquefaction analysis in the vicinity of MLML shows a Liquefaction Safety Factor of 0.51 and a $6.1 \mathrm{~m}$ thick liquefiable horizon. By comparison, liquefaction severity was least at MBARI which has a safety factor of 0.68 and a $3.7 \mathrm{~m}$ thick liquefiable horizon (Fig. 6).

Shallow ground water is one of the prerequisites for liquefaction, and ground water elevation determines the thickness of the liquefiable horizon. If the earthquake had occurred when the tidally influenced ground water beneath the spit was significantly higher or lower, liquefaction effects would have been different. The magnitude of tidal influence has been investigated at the spit and a $0.91 \mathrm{~m}$ tidal lag that decreases away from the harbor has been reported (Rutherford \& Chekene, 1988).

Historic and prehistoric buried margins of channels and shorelines are reflected in the surficial distribution of sand boils and lateral spreading cracks in and around Moss Landing. There is some correlation between the historic shoreline locations and 1989 lateral spreading cracks, particularly on the eastern side of the spit (Fig. 5). Postearthquake reconnaissance mapping at Moss Landing State Beach (Fig. 2) revealed a linear arrangement of sand boils conforming to the pre-1930's Salinas River channel. Subsurface seismic profiling in the harbor (Fig. 6B) indicated the presence of an old buried fluvial channel in the vicinity of Peninsula Diesel (M.T. Ledbetter, personal 
comm., 1992). Arcuate lateral spreading cracks at Peninsula Diesel (Fig. 3C) could be a surface expression of a buried curving fluvial channel shoreline although these cracks also parallel the 1910 shoreline (Fig. 5B). Borchardt (1991) noted linear sand volcano alignment at Zmudowski State Beach (3.5 km north of Moss Landing), also coincident with former slough or river margins.

Onshore damage and liquefaction effects may be related to offshore slumping and liquefaction, which occurred at the canyon head and offshore. Onshore liquefiable soil horizons and offshore liquefaction lobes and sand boils are at similar depths $(10 \mathrm{~m})$ (Fig. 7A) and borings indicate the nearshore area is underlain by coarse-grained, liquefiable sands (Fig. 6D). Some liquefaction features paralleled onshore features (Greene et al., 1991) and onshore lateral spreading cracks in the area east of the pier near MLML are obliquely parallel to the canyon head $100 \mathrm{~m}$ to the west. Lateral spreading toward free faces 300-500 m distant was noted after the Loma Prieta earthquake (J. Tinsley, personal comm. 1990). A pipeline was offset $0.5 \mathrm{~m}$ in the canyon head area and the onshore buildings closest to the canyon head (MLML and General Fish) were severely damaged. No damage or tilting of the MLML pier supports adjacent to the southern arm of the canyon was noted after the earthquake and comparison with photographs taken before the earthquake did not reveal any discernible change. The pier has been affected by past seismic events and normal erosional processes in the canyon head area. Piers have been located at MLML since 1866 (Elliot \& Moore, 1881) and Lawson (1908) noted after the 1906 earthquake that "at places along the pier where the water was formerly 6 feet [1.8 
m] deep, it now has a depth of 18 or 20 feet [5.5 or $6.1 \mathrm{~m}$ ]. MLML personnel have noticed a shortening of the pier over the last 20 years (Gardner-Taggart and Barminski, 1991). Failure of the concrete seawall over the 1989-1990 winter may have been caused by the earthquake (Griggs, 1990). Movement of sand by slumping and lateral spreading from the beach into the canyon head may have lowered the beach and created a shortage of beach sand which allowed the moderate storms of the following winter to undermine the seawall (Griggs, 1990). During the spring of 1990 it was noted that the surface underneath MLML's pier was completely scoured of sand and the normal offshore winter sand bars were absent (John Oliver, personal comm., 1990).

Damage to MLML was due in part to the geological conditions underlying the site, proximity to Monterey Canyon, and foundation failure. No precautions against liquefaction were taken in the design and standard quality construction of the MLML 1982 addition. Liquefaction was considered in the design of MBARI which was above standard construction quality.

\section{Ground Motion}

Peak horizontal ground motion at Moss Landing is estimated to have been between 0.24 and $0.48 \mathrm{~g}$ (0.36 g median) using Woodward-Clyde Consultants' (1990) estimated rock-site peak horizontal acceleration of $0.16 \mathrm{~g}$ and adjusting for soil conditions. The deep soft soil column and shallow ground water underlying Moss Landing amplify ground motions and peak horizontal accelerations during the Loma Prieta earthquake at soft soil 
sites similar to Moss Landing spit were about 1.5 to 3 times those obtained on rock sites (Idriss, 1991). The estimated $0.36 \mathrm{~g}$ peak horizontal ground acceleration at Moss Landing is comparable to quantitative data from the nearest accelerograph, a peak horizontal ground acceleration of $0.39 \mathrm{~g}$ was recorded in Watsonville $(15 \mathrm{~km}$ from Moss Landing and $18 \mathrm{~km}$ from the epicenter) on relatively older alluvial sediments. An estimated median peak horizontal ground motion of $0.25 \mathrm{~g}$ (Woodward-Clyde Consultants, 1990) was used for liquefaction analyses. If analyses were performed using a higher peak horizontal ground acceleration of $0.36 \mathrm{~g}$ there would be no effect on the relative liquefaction potential of the shallow sand, silt, and clay but analyses using the higher $(0.39 \mathrm{~g})$ estimate would probably determine that the deeper sand and gravelly sand below the silt and clay to a depth of $12.2 \mathrm{~m}$ below the surface is liquefiable in some areas. The deeper sand and gravelly sand determined to be marginally non-liquefiable using the lower $(0.25 \mathrm{~g})$ estimate would probably be in the liquefiable range at MLML, the Fire Station, and Woodward Marine. The increase in thickness of the liquefiable soil horizons would be; $4.0 \mathrm{~m}$ at MLML, $3.4 \mathrm{~m}$ at the Fire Station, and $2.7 \mathrm{~m}$ at Woodward Marine. At MBARI the deeper sand and gravelly sand is relatively denser with accordingly greater resistance to liquefaction compared to other locations and probably not liquefy under the higher acceleration $(0.36 \mathrm{~g})$.

Horizontal slope deflection measurements before and after the earthquake (Harding Lawson Associates, 1990) indicate more slope movement occurred at General Fish $(27 \mathrm{~cm})$ in liquefiable sand and soft silt than MBARI $(7.1 \mathrm{~cm})$ in relatively less 
liquefiable sand. Measurements indicate deflection was greatest near the surface in loose sands and soft silt beneath General Fish. Deflection decreased with depth and little slope movement occurred in the soft to stiff clay ( $\sim .6 \mathrm{~m}$ below the surface) and underlying generally dense sand.

\section{Shear Wave Analyses}

Shear wave velocities are influenced by many of the same geologic variables that determine the severity of liquefaction such as confinement, stress history, and geologic age. Shear wave velocities are related to unconfined compressive strength, SPT values and compression (Bailey and Van Alstine, 1975). Shear wave analyses shows that low near surface shear wave velocities are associated with values of increased ground response and site response studies in Santa Cruz (Cranswick et al., 1990) indicate that amplification factors of 5 to 10 were associated with shear wave velocities of $80-150 \mathrm{~m} / \mathrm{s}$ in San Lorenzo River alluvium. The uppermost loose sand at Moss Landing has a shear wave velocity of $146 \mathrm{~m} / \mathrm{s}$ (Fig 8) which is typical for very recent uncompacted sands (Dobrin, 1976). Comparison of shear wave velocities indicates the threshold velocity for liquefaction at Moss Landing is $0.1 \mathrm{~g}$ (Tokimatsu and Ushida, 1990), much higher velocities are predicted for Moss Landing from earthquakes on a number of faults in the area. 


\begin{tabular}{|c|c|c|c|c|c|}
\hline 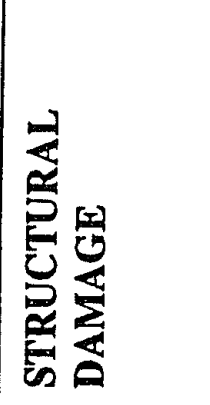 & 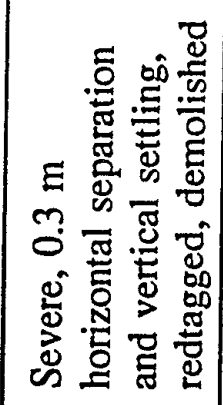 & 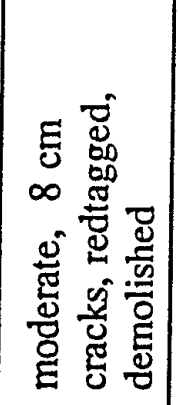 & 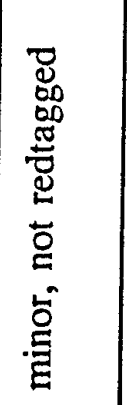 & 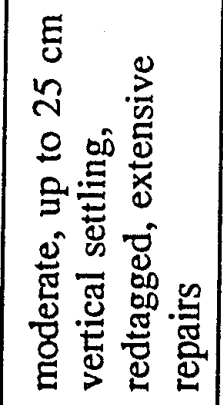 & 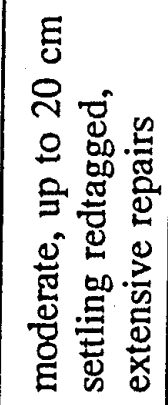 \\
\hline 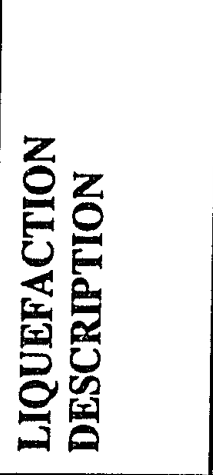 & 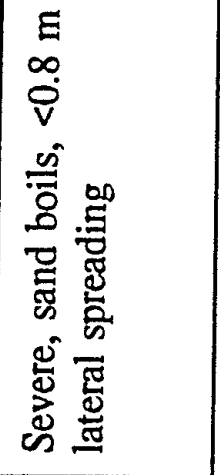 & 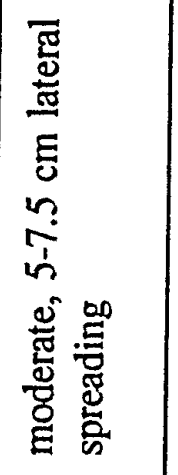 & 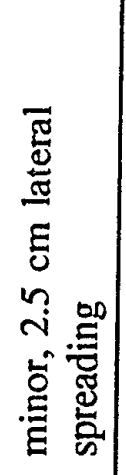 & 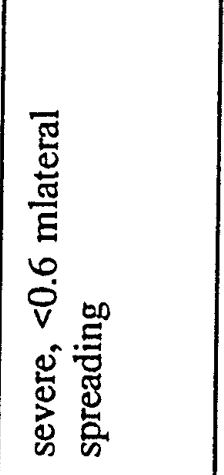 & 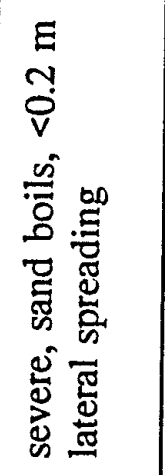 \\
\hline 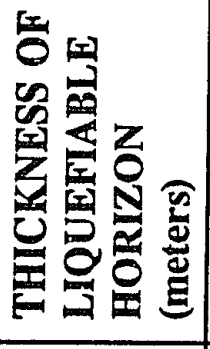 & 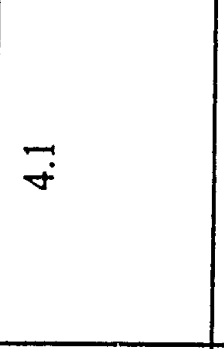 & $m$ & $\tilde{n}$ & $m$ & $\ddot{\forall}$ \\
\hline 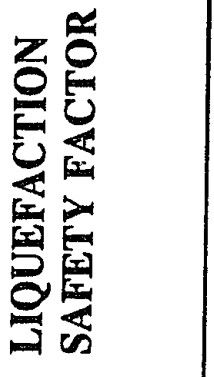 & $\bar{n}$ & กี & $\stackrel{\infty}{0}$ & กิ? & $\bar{y}$ \\
\hline Ex & $\underset{\sum}{\stackrel{2}{Z}}$ & 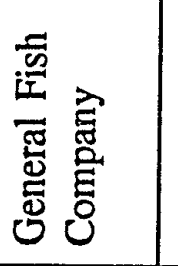 & $\frac{\vec{\alpha}}{\Sigma}$ & 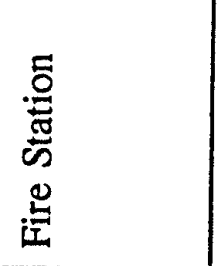 & 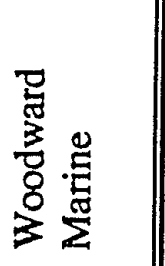 \\
\hline
\end{tabular}




\section{CONCLUSIONS}

The Loma Prieta earthquake demonstrated that Moss Landing is one of the locales most affected by earthquake-induced liquefaction. As in other areas, including coastal Santa Cruz County and the Marina District of San Francisco, liquefaction induced ground failure of the soil increased the severity of earthquake effects. The differing degrees of building damage and uneven distribution of liquefaction effects documented at Moss Landing spit after the Loma Prieta earthquake are related to sediment type, distribution and age of sediment, liquefaction potential and thickness of liquefiable sediments, proximity to a free faces at the head of Monterey Canyon and along shoreline banks of the harbor, and building design and construction.

The spit is underlain by loose, fine to medium grained, well-sorted dune and beach sand, which is saturated at shallow depth. Seismic profiling and geologic interpretation indicate that slough and river deposits, which is highly variable in thickness and extent, is found at greater depths. Calculated liquefaction potential is very high for the uppermost sand of variable thickness. Site specific information indicates that the greatest thickness of liquefiable sand corresponds with the greatest severity of liquefaction and conversely the least thickness of sand corresponds with the least liquefaction severity. Sewer line breaks are also concentrated in areas of high liquefaction potential and thick sand lenses. Horizontal slope deflection was greater in areas underlain by thick sand. Historic and prehistoric buried margins of channels and shorelines are reflected in the 
surficial distribution of liquefaction effects. Some correlation between the historic shoreline locations and 1989 lateral spreading cracks was noted. The marine environment also experienced severe liquefaction which may have affected onshore structures and contributed to the subsequent collapse of the MLML seawall. The two buildings closest to the Monterey Canyon were severely damaged.

Peak horizontal ground motion at Moss Landing is estimated to have been between 0.24 and $0.48 \mathrm{~g}(0.36 \mathrm{~g}$ median). Shear wave velocities corresponded to the observed lithology and were within the expected range for the sediment types found at Moss Landing. Shear wave velocities corroborate the liquefaction analysis results and indicate the threshold velocity for liquefaction at Moss Landing is $0.1 \mathrm{~g}$ (Tokimatsu and Ushida, 1990). Probability analyses predict earthquakes will generate velocities exceeding $0.1 \mathrm{~g}$ at Moss Landing in the near future (Working Group on Earthquake Probabilities, 1990).

Moss Landing is an excellent location for study of future earthquake effects because it has many features in common with other coastal marine communities in proximity to submarine canyons, it has experienced seventeen to twenty-one MMI VI-VIII seismic events since 1810 (McCrory et al., 1977) and with an apparent return to the higher rates of earthquake activity of the 1800 's following a post-1906 lull in earthquake rates, there is a $60 \%$ chance that another major earthquake will affect Moss Landing within the next 30 years (Working Group on Earthquake Probabilities, 1990). A comparative geotechnical study of pre-earthquake and post-earthquake soil conditions is currently underway and ground motion instruments have been placed at Moss Landing 
(R. Boulanger, personal comm., 1993). Numerous investigations in the area both before and after the earthquake have formed a solid database for study of future earthquakes. State beaches north and south of Moss Landing could be used to compare variations of future earthquake surface manifestations on developed and undeveloped land. In addition, long-term monitoring of the existing slope indicator casings located on the spit and additional investigation in the canyon head area should be initiated before the next earthquake strikes Moss Landing. 


\section{REFERENCES}

Bailey, A.D., and Van Alstine, C.L., 1975, Down-hole shear wave and soils study: Unpublished report for Nimbus Instruments, West Sacramento, CA, 8 p.

Blake, T.F., and Blake, K.R., 1986, Liquefy2, A Computer Program for the Empirical Prediction of Earthquake-Induced Liquefaction Potential, Users Manual: Blake and Blake, Newbury Park, CA, 85 p.

Borchardt, G., 1991, Liquefaction and Shaking Damage in the Watsonville and Oakland Areas and it's Implications for Earthquake Planning Scenarios. In Baldwin, J.E. and Sitar N. (editors), Loma Prieta earthquake: Engineering Geologic Perspectives: Association of Engineering Geologists Special Publication No. 1, Association of Engineering Geologists, Sudbury, MA., pp. 83-103

Boulanger, R., 1993, personal communication, Department of Civil Engineering, University of California at Davis, Davis CA, 95616

Brian Kangas-Foulk Inc., 1989, Post-earthquake survey, Moss Landing Marine Laboratories: Unpublished report for California State University, San Jose, CA, 1 p.

Cooper Clark \& Associates, 1978, Preliminary Geotechnical Evaluation, Moss Landing Marine Laboratories: Unpublished report for California State University, San Jose, CA, $9 \mathrm{p}$.

Cranswick, E., King, K.W., Spudich, P., Carver, D.L., Worley, D.M., Banfill, R., 1990, Site Response Across the Downtown Santa Cruz Alluvial Basin: Eos, February 20, 1990, pp. 287.

Dames \& Moore, 1963, Soil borings for PG \& E Moss Landing power plants: Unpublished report for Pacific Gas \& Electric Company, San Francisco, CA, 8 p.

Dietz, L.D., and Ellsworth, W.L., 1990, The October 17, 1989 Loma Prieta earthquake and it's aftershocks: geometry of the sequence from high-resolution locations: Geophysical Research Letters, Vol. 17, pp. 1417-1420

Dobrin, M.B., 1976, Introduction To Geophysical Prospecting: McGraw-Hill Inc. publishers, New York NY, 630 p. 
Dobry, R., Idriss, I.M., and $\mathrm{Ng}, \mathrm{E} ., \mathrm{1978}$, Duration Characteristics of horizontal components of strong motion earthquake records: Bulletin of the Seismological Society of America, Vol. 68, no. 4, pp. 1487-1520

Dupré, W.R., 1975, Quaternary history of the Watsonville lowlands, north-central Monterey Bay region, California: Unpublished Ph.D. Thesis, Department of Geology, Stanford University, Stanford, CA, 145 p.

Dupré, W.R., 1990, personal communication, University of Houston, Department of Geosciences, Houston, TX, 77204-5503

Dupré, W.R., Tinsley, J.C., III, 1980, Geology and liquefaction potential of northern Monterey and southern Santa Cruz Counties, California: U.S. Geological Survey Miscellaneous Field Studies Map 1199, U.S. Geological Survey, Denver, CO, scale $1: 62,500,2$ sheets.

Elliott and Moore (publishers), 1881, History of Monterey County, California with Illustrations: Valley Publishers, Fresno CA, 1979 edition, 197 p.

Foxx, Nielson and Associates, 1990, Geologic Investigation, Woodward Marine, Moss Landing, Monterey County, California: Unpublished report for Woodward Marine, Moss Landing, CA, $51 \mathrm{p}$.

Gardner-Taggart, J.M., and Barminski, R.F., 1991, Short Period Wave Generation in Moss Landing Harbor caused by Offshore Landslides Induced By The Loma Prieta Earthquake: Geophysical Research Letters, Vol. 18, No. 7, pp. 1277-1280

Gordon, B.L., 1987, Monterey Bay Area: Natural History and Cultural Imprints: Boxwood Press, Pacific Grove, CA, 321 p.

Greene, H.G., Gardner-Taggart, J., Ledbetter, M.L., Barminski, R.F., Chase, T.E., Hicks, K.R., and Baxter, C., 1991, Offshore and onshore liquefaction at Moss Landing Spit-result of the October 17, 1989 earthquake: Geology, Vol. 19, pp. 945-949.

Greene, H.G., 1977, Geology of the Monterey Bay region: U.S. Geological Survey OpenFile Report 77-718, U.S. Geological Survey, Denver, CO, 347 p.

Green Line Underground Video, 1989; Videotape of sewer line damage at Moss Landing: Unpublished videotape report for Monterey County Public Works Department, Salinas, CA 
Griggs G.B., 1990, An evaluation of coastal hazards at Moss Landing Marine Laboratory site: Unpublished report prepared for Chancellor's Office of California State University, Long Beach CA, $42 \mathrm{p}$.

Griggs, G.B and Savoy, L.E., 1985, Living with the California Coast: Duke University Press, Durham, NC, 394 p.

Harding Lawson Associates, 1988, Geotechnical Investigation, Dredging and Slope Improvements, Moss Landing South Harbor, Moss Landing California: Unpublished report for Moss Landing Harbor District, Moss Landing, CA, 21 p.

Harding Lawson Associates, 1990, Slope Indicator Readings, Moss Landing California: Unpublished report for Moss Landing Harbor District, Moss Landing, CA, 25 p.

Hatano, Tom, 1991, personal communication, Hatano Structural and Civil Design, 345 Kolb Avenue, Monterey, CA 93940

Housner, G. W., and the Committee on Earthquake Engineering, National Research Council, 1985, Liquefaction of Soils During Earthquakes: National Academy Press, Washington, D.C., 240 p.

Idriss, I.M., 1991, Response of Soft Soil Sites during Earthquakes, in Duncan, J.M. (editor), H. Bolton Seed Memorial Symposium Proceedings: Vol. 2, pp. 273-289

Jo Crosby \& Associates, Geotechnical Consultants, 1981, Geotechnical Investigation, Proposed Marine Laboratory, Moss Landing, California: Unpublished report for Trustees of the California State University and Colleges, Long Beach, CA, 12 p.

Lawson, A.C. (chairman), 1908, The California earthquake of April 18, 1906: Report of the State Earthquake Investigation Commission, Carnegie Institution of Washington Publication 87, Washington, D.C., 3 Vols.

Ledbetter, M.L., 1989, 1991, personal communication, National Undersea Research Program, Silver Spring Metro Center 1, 1335 East-West Highway, Code R/OR2, Silver Spring, MD, 20910

Marcuson, W.F., and Bieganousky, W.A., 1977, SPT and Relative Density in Coarse Sands: Journal of the Geotechnical Engineering Division, ASCE, 103(GT11), pp. 12951309 
McCrory, P.A., Greene, H.G., Lajoie, K.R., 1977, Map Showing Earthquake Intensity Zonation And Distribution Of Quaternary Deposits, San Mateo, Santa Cruz, And Monterey Counties, California: U.S. Geological Survey Miscellaneous Field Studies Map MF-903, U.S. Geological Survey, Denver, CO, scale 1:250,000

McNutt, S.R., and Toppozada T.R., 1990, Seismological Aspects Of The 17 October 1989 Earthquake. In The Loma Prieta (Santa Cruz Mountains), California, Earthquake Of 17 October 1989: California Division of Mines and Geology Special Publication 104, Sacramento, CA, pp. 11-27

Messick, E., 1989, County gives OK for reopening today of Moss Landing "island": The Herald, October 31, 1989, 68th year, No. 139, Monterey, California, pp. 1

M. Jacobs \& Associates, 1990, Geotechnical Investigation for Woodward Marine, Moss Landing, California: Unpublished report for Woodward Marine, Moss Landing, CA, 50 p.

M. Jacobs \& Associates, 1991, Geotechnical Investigation for Moss Landing Marine Laboratory, Marine Operations Facility, Moss Landing, California: Unpublished report for Moss Landing Marine Laboratories, Moss Landing, CA, 48 p.

Okey, Tom, 1990, personal communication, Moss Landing Marine Laboratories, P.O. Box 450, Moss Landing, CA 95039

Oliver, John, 1990, personal communication, Moss Landing Marine Laboratories, P.O. Box 450, Moss Landing, CA 95039

Page, B.M., 1989, The Salinian block, in Wahrhaftig, C. and Sloan, D. (editors), Geology of San Francisco and vicinity: Field Trip Guidebook T-105, 28th International Geological Congress, American Geophysical Union, Washington, D.C., pp. 16-20

Plafker, G., and Galloway, J.P. (editors), 1989, Lessons learned from the Loma Prieta, California, earthquake of October 17, 1989: U.S. Geological Survey Circular 1045, U.S. Geological Survey, Denver, CO, 48 p.

Redpath, B.B., 1991, Results of downhole shear-wave velocity measurements at Moss Landing: Unpublished report for Robert Barminski, Moss Landing Marine Laboratories, Moss Landing, CA, 7 p.

Richter, C.F., 1958, Elementary Seismology: W.H. Freeman and Company, San Francisco, CA, $768 \mathrm{p}$. 
Rutherford \& Chekene, 1987, Geological Hazard Evaluation, Monterey Bay Aquarium Research Institute, Moss Landing Facility, California: Unpublished report for Monterey Bay Aquarium Research Institute, Pacific Grove, CA, 43 p.

Rutherford \& Chekene, 1988, Geotechnical Investigation, Monterey Bay Aquarium Research Institute, Moss Landing Facility, California: Unpublished report for Monterey Bay Aquarium Research Institute, Pacific Grove, CA, 46 p.

Rutherford \& Chekene, 1989, Post-Earthquake Survey, Monterey Bay Aquarium Research Institute, Moss Landing Facility, California: Unpublished report for Monterey Bay Aquarium Research Institute, Pacific Grove, CA, 1 p.

Rutherford, John, 1990, personal communication, Rutherford \& Chekene, Consulting Engineers, 487 Bryant Street, San Francisco, CA, 94107

Salinas Weekly Index, 1906, Disastrous Earthquake: April 19, 1906, Vol. 34, Salinas, CA, pp. 1.

Seed, H.B. and Idriss, I.M., 1982, Ground Motions and Soil Liquefaction During Earthquakes: Earthquake Engineering Research Institute, El Cerrito, CA, 134 p.

Seed, H.B., Tokimatsu, K., Harder, L.F., and Chung, R.M., 1985, Influence of SPT Procedures in Soil Liquefaction Resistance Evaluations: Journal of Geotechnical Engineering, Vol. 111, No. 12, pp. 1425-1445.

Shepard, F.P., and Dill, R.F., 1966, Submarine canyons and other sea valleys: Rand McNally, Chicago, $\mathrm{L}, 381 \mathrm{p}$.

Stover, C.W., Reagor, B.G., Baldwin, F.W., and Brewer, L.R., 1990, Preliminary isoseismal map for the Santa Cruz (Loma Prieta), California, earthquake of October 18, 1989 UTC: U.S. Geological Survey Open-File Report 90-18, U.S. Geological Survey, Denver, CO, $24 \mathrm{p}$.

Tinsley, J.C., 1990, personal communication, U.S. Geological Survey, Branch of Western Regional Geology, 345 Middlefield Rd, MS 975, Menlo Park, CA., 94025

Tokimatsu, K., and Ushida, A., 1990, Correlation between liquefaction resistance and shear wave velocity: Soils and Foundations, Japanese Society of Soil Mechanics and Foundation Engineering, Vol. 30, No. 2, pp. 33-42 
Tokimatsu, K., and Yoshimi, Y., 1983, Empirical correlation of soil liquefaction based on SPT N-value and fines content: Soils and Foundations, Japanese Society of Soil Mechanics and Foundation Engineering, Vol. 23, No. 4, pp. 56-74

Tuttle, M., Cowie, P., Tinsley, J., Benett, M., and Berrill, J., 1990, Liquefaction and foundation failure of Chevron oil and gasoline tanks at Moss Landing, California: Geophysical Research Letters, Vol. 17, No. 10, pp. 1797-1800

United States Department of Commerce and Labor, 1854, Coast and Geodetic Survey: Sheet T-473, scale 1:10,000

United States Department of Commerce and Labor, 1910, Coast and Geodetic Survey: Sheet T-473A, scale 1:10,000

United States Department of Commerce and Labor, 1933, Coast and Geodetic Survey: Sheet T-4788, scale 1:10,000

United States Department of Interior, Bureau of Reclamation, 1986, Engineering Geology Field Manual: Denver, CO, 598 p.

Woodward-Clyde Consultants, 1990, Phase 1 - Geotechnical Study, Marine Biology Laboratory, California State University, Moss Landing, California: Unpublished report for California State University, Los Alamitos, CA, 16 p.

Working Group on Earthquake Probabilities, 1990, Probability of Large Earthquakes in the San Francisco Bay Region, California: U.S. Geological Survey Circular 1053, U.S. Geological Survey, Denver, CO, 51 p.

Youd, T.L., and Bennett, M.J., 1983, Liquefaction sites, Imperial Valley, California: American Society of Civil Engineers Journal of the Geotechnical Division, Vol. 109, No. 3, pp. $440-457$

Youd, T.L. and Hoose, S.N., 1978, Historic ground failures in northern California triggered by earthquakes: U.S. Geological Survey Professional Paper 993, U.S. Geological Survey, Denver, CO, 177 p. 